(c) American Dairy Science Association, 2002.

\title{
Milk Response to Concentrate Supplementation of High Producing Dairy Cows Grazing at Two Pasture Allowances
}

\author{
F. Bargo, ${ }^{1}$ L. D. Muller, J. E. Delahoy, and T. W. Cassidy \\ Department of Dairy and Animal Science \\ The Pennsylvania State University, University Park 16802
}

\section{ABSTRACT}

Twenty multiparous Holstein cows (four ruminally cannulated) in five $4 \times 4$ Latin squares with 21 -d periods were used to study the effect of concentrate supplementation when grazed at two pasture allowances. The four dietary treatments resulted from the combination of two pasture allowance targets (low, $25 \mathrm{vs}$. high, $40 \mathrm{~kg}$ of dry matter/cow per day) and two concentrate supplementation levels (zero vs. $1 \mathrm{~kg}$ of concentrate $/ 4 \mathrm{~kg}$ of milk). Concentrate supplementation decreased pasture dry matter intake $2.0 \mathrm{~kg} / \mathrm{d}$ at the low pasture allowance $(17.5$ vs. $15.5 \mathrm{~kg} / \mathrm{d})$ and $4.4 \mathrm{~kg} / \mathrm{d}$ at the high pasture allowance (20.5 vs. $16.1 \mathrm{~kg} / \mathrm{d})$. Substitution rate was lower at the low pasture allowance $(0.26 \mathrm{~kg}$ pasture $/ \mathrm{kg}$ concentrate) than at the high pasture allowance ( 0.55 $\mathrm{kg}$ of pasture/kg of concentrate). Total dry matter intake of both supplemented treatments averaged 24.4 $\mathrm{kg} / \mathrm{d}$. Milk production of both supplemented treatments averaged $29.8 \mathrm{~kg} / \mathrm{d}$, but was increased with higher pasture allowance in the unsupplemented treatments (19.1 vs. $22.2 \mathrm{~kg} / \mathrm{d}$ ). Milk response to concentrate supplementation was 1.36 and $0.96 \mathrm{~kg}$ of milk/ $/ \mathrm{kg}$ of concentrate for the low and high pasture allowances, respectively. Concentrate supplementation reduced milk fat percentage but increased milk protein percentage. Rumen $\mathrm{pH}$ and $\mathrm{NH}_{3}-\mathrm{N}$ concentration were decreased with concentrate supplementation. Substitution rate was likely related to both negative associative effects in the rumen (reductions in rumen $\mathrm{pH}$, rate of pasture digestion, and NDF digestibility) and reductions in grazing time. The latter was more important, quantitatively explaining at least $80 \%$ of the reduction in pasture dry matter intake observed.

(Key words: pasture allowance, concentrate supplementation, substitution rate, milk response)

Received September 26, 2001.

Accepted January 14, 2002.

Corresponding author: L. D. Muller; e-mail: lmuller@psu.edu.

${ }^{1}$ Current address: Dairy Nutrition Services, Inc., Chandler, AZ 85244; e-mail: fbargo@dns-ans.com.
Abbreviation key: $\mathbf{C S}=$ concentrate supplementation, Low PA-U = low pasture allowance-unsupplemented, Low PA-CS = low pasture allowance-concentrate supplementation, High PA-U = high pasture allowance-unsupplemented, High PA-CS = high pasture allowance-concentrate supplementation, IVDMD = in vitro DM digestibility, MUN = milk urea nitrogen, $\mathbf{P A}=$ pasture allowance, $\mathbf{P U N}=$ plasma urea nitrogen.

\section{INTRODUCTION}

Energy is the first limiting nutrient for high producing cows grazing high quality pastures as the only feed (Kolver and Muller, 1998). Compared with cows on a nutritionally balanced TMR, early lactation cows grazing high quality pasture with no supplement had lower total DMI (19.0 vs. $23.4 \mathrm{~kg} / \mathrm{d}$ ) and milk production (29.6 vs. $44.1 \mathrm{~kg} / \mathrm{d}$ ). While the intake of CP and NDF did not differ between cows fed pasture and TMR, the intake of $\mathrm{DM}$ and $\mathrm{NE}_{\mathrm{L}}$ was significantly lower in the pasturefed cows, suggesting that high producing dairy cows on pasture need supplemental energy to reach their genetic potential for intake and milk production.

Substitution rate is defined as the decrease in pasture intake per kilogram of supplemental feed (Kellaway and Porta, 1993). Several animal, pasture, and supplement factors affect substitution rate, including pasture allowance (PA), amount of concentrate fed, digestibility of pasture, chemical and physical properties of the concentrate, and stage of lactation (Kellaway and Porta, 1993). Among these factors, the amount of pasture offered per cow daily or PA has a major effect on substitution rate. Several studies have reported that substitution rate is greater at high PA (Meijs and Hoekstra, 1984; Stakelum, 1986; Grainger and Mathews, 1989; Robaina et al., 1998). Research in Ireland (Stakelum, 1986) found substitution rates of 0.28 and 0.59 for PA of 16 and $24 \mathrm{~kg}$ of DM/cow per day, respectively. Robaina et al. (1998) reported a $0.57-\mathrm{kg}$ reduction in pasture intake/ $\mathrm{kg}$ of grain at a PA of $42.3 \mathrm{~kg} \mathrm{DM} /$ cow per day, and $0.31 \mathrm{~kg}$ of pasture $/ \mathrm{kg}$ of supplement at a PA of $20 \mathrm{~kg}$ of DM/cow per day. All of these studies were 
conducted with dairy cows producing less than $20 \mathrm{~kg} /$ $\mathrm{d}$ of milk.

Substitution rate is a major factor contributing to the variable response in milk yield to concentrate supplementation (CS; Kellaway and Porta, 1993). The lower the substitution rate, the greater the milk response obtained per kilogram of supplement. In the review of Kellaway and Porta (1993), which summarized research primarily with cows producing less than $20 \mathrm{~kg} /$ $\mathrm{d}$ of milk, response averaged $0.6 \mathrm{~kg}$ milk $/ \mathrm{kg}$ concentrate when cows grazed restricted pasture (low PA) and almost $0 \mathrm{~kg}$ milk/kg concentrate when cows grazed pasture ad libitum (high PA). There is a lack of information on substitution rate and milk response to CS of high producing dairy cows grazing at different PA. Dixon and Stockdale (1999) suggested that substitution rate is low when energy intake is low in relation to the cow's energy requirement. Low substitution rate is expected for cows grazing low to medium digestibility pasture (Dixon and Stockdale, 1999; Stockdale, 1999). Therefore, a low substitution rate and high milk response may be expected in high producing dairy cows because of the high genetic potential for intake and milk production and the low partition of the concentrate energy for maintenance. The objectives of this study were to determine the substitution rate and milk response to CS of high producing dairy cows grazing at two PA and to identify the factors related to the substitution rate.

\section{MATERIALS AND METHODS}

\section{Cows and Treatments}

Twenty multiparous Holstein cows (four fitted with ruminal cannulas) [BW, $631 \pm 71 \mathrm{~kg}$; milk yield, 45.8 $\pm 6.6 \mathrm{~kg} / \mathrm{d}$; parity, $2.8 \pm 0.8$; DIM, $101 \pm 35$ (mean \pm SD)] were blocked by DIM (one block of ruminally cannulated cows) and randomly assigned to four dietary treatments within five $4 \times 4$ Latin squares with 21 -d periods. Cows were selected from The Pennsylvania State University Dairy Cattle Research and Education Center (University Park, PA), which averaged 11,436 $\mathrm{kg}$ of milk and $363 \mathrm{~kg}$ of protein per lactation in 1999 . The first two periods were conducted during the spring (period 1 from May 10 to May 30; period 2 from May 31 to June 20), and the last two periods were conducted during the fall (period 3 from September 3 to September 23; period 4 from September 24 to October 14) of 1999. Between the spring and fall periods, all cows were housed in a tie stall and fed a nutritionally balanced TMR because of the drought period that occurred during the summer, which decreased both quality of pasture fed and quantity of pasture availability. With 75 $\mathrm{d}$ between periods 2 and 3 , both stage of lactation and season (spring vs. fall) are confounded into the period effect.

The four dietary treatments were arranged in a $2 \times$ 2 factorial. Factors evaluated were PA (low vs. high) and CS (unsupplemented vs. supplemented). The four dietary treatments resulted from the combination of the two levels of these two factors: low PA-unsupplemented (Low PA-U); low PA—concentrate supplementation (Low PA-CS); high PA — unsupplemented (High PA-U); and high PA-concentrate supplementation (High PA-CS).

Pasture allowance targets were 25 and $40 \mathrm{~kg} \mathrm{DM} /$ cow per day to the ground level for the low and high PA treatments, respectively. To achieve these targets, pregrazing pasture mass was measured every $2 \mathrm{~d}$ to adjust the size of the paddock and the amount of pasture offered per cow on a daily basis (PA). Pregrazing pasture mass ( $\mathrm{kg}$ of $\mathrm{DM} / \mathrm{ha}$ ) was measured by cutting 10 quadrants $\left(0.124 \mathrm{~m}^{2} /\right.$ quadrant $)$ of pasture to ground level, and drying at $55^{\circ} \mathrm{C}$ in a forced air oven. A new paddock was constructed daily using a temporary polywire. A second polywire fence was used to prevent back-grazing. New paddocks were given to the cows each morning at approximately $0700 \mathrm{~h}$, after the a.m. milking. Half of the cows $(n=10)$ grazed at low PA, and half of the cows $(n=10)$ grazed at high PA divided by a temporary polywire. Pasture botanical composition was measured at the end of each of the four periods and averaged 50\% smooth bromegrass (Bromus inermis L.), 33\% orchardgrass (Dactylis glomerata L.), 7\% Kentucky bluegrass (Poa pratensis L.), and $10 \%$ weeds and dead material. Pasture was fertilized with $\mathrm{N}$ before the beginning of the first period (April 25) and the beginning of the third period (August 18) at a rate of $50 \mathrm{~kg}$ $\mathrm{N} / \mathrm{ha}$.

Unsupplemented cows received no CS, but were fed a mineral-vitamin mix at a rate of $1 \mathrm{~kg} / \mathrm{d}$ per cow to avoid mineral and vitamin deficiencies. The actual amount of concentrate offered per cow in the supplemented group was $1 \mathrm{~kg}$ of concentrate $/ 4 \mathrm{~kg}$ of milk at the beginning of period 1 using the pretrial milk production. An upper limit of $10 \mathrm{~kg}$ of $\mathrm{DM} /$ cow per day was established for cows producing more than $40 \mathrm{~kg} / \mathrm{d}$ of milk. The amount of concentrate offered was adjusted before the beginning of period 3 using the milk production level before that period. Both the mineral-vitamin and the concentrate mixes were fed individually in two equal feedings after the a.m. and p.m. milking. The ingredient and chemical composition of the mineralvitamin and the concentrate mixes used for the unsupplemented and supplemented cows, respectively, is shown in Table 1 . Cows were milked twice daily at 0600 and $1730 \mathrm{~h}$. Walking distance from pasture to the milking parlor averaged $0.9 \mathrm{~km}$ (range: 0.75 to $1.20 \mathrm{~km}$ ). 
Table 1. Ingredient and chemical composition (mean \pm SD) of the mineral-vitamin mix and the concentrate used in the unsupplemented and supplemented pasture treatments, respectively.

\begin{tabular}{llc}
\hline & Mineral-vitamin mix & Concentrate \\
\hline Ingredient composition, \% of DM & & \\
Shell dry corn & 29.3 & 62.3 \\
Wheat midds & $\ldots$ & 10.4 \\
Barley grain & $\ldots$ & 7.8 \\
Roasted soybeans & $\ldots$ & 5.2 \\
Molasses & 24.4 & 5.2 \\
Corn gluten meal & $\ldots$ & 2.6 \\
Limestone & $\ldots$ & 1.3 \\
Dicalcium phosphate & 19.5 & 2.1 \\
Salt & 11.7 & 1.4 \\
Magnesium oxide & 6.8 & 0.8 \\
Dynamate & 4.9 & 0.6 \\
Selenium premix & 1.5 & 0.15 \\
PS TM premix \#4 & 1.4 & 0.1 \\
Vitamins A, D, E & 0.5 & 0.05 \\
Chemical composition & & \\
DM, $\%$ & $95.1 \pm 1.4$ & $90.8 \pm 0.5$ \\
\% DM & & \\
OM, \% & $57.4 \pm 6.0$ & $91.6 \pm 0.6$ \\
CP, \% & $9.5 \pm 0.2$ & $13.4 \pm 0.9$ \\
NSC, \% & $17.3 \pm 2.9$ & $59.2 \pm 2.7$ \\
NDF, \% & $17.9 \pm 2.7$ & $17.4 \pm 1.1$ \\
ADF, \% & $11.4 \pm 1.5$ & $6.5 \pm 0.6$ \\
In vitro DM digestibility, \% & $87.7 \pm 2.6$ & $91.6 \pm 6.2$ \\
\hline
\end{tabular}

\section{Experimental Measures and Sample Analyses}

During each of the four 21-d periods, the first $10 \mathrm{~d}$ were used to adjust the cows to the different dietary treatments, and the last $11 \mathrm{~d}$ were used for experimental measures.

Intake was estimated from d 15 to 19 of each period using $\mathrm{Cr}_{2} \mathrm{O}_{3}$ as an indigestible fecal marker. The indigestible fecal marker $\mathrm{Cr}_{2} \mathrm{O}_{3}$ was dosed twice daily (10 $\mathrm{g}$ of $\mathrm{Cr}_{2} \mathrm{O}_{3} / \mathrm{d}$ ) after each milking (0630 and $1800 \mathrm{~h}$, approximately) for $10 \mathrm{~d}$ beginning on $\mathrm{d} 10$ of each period. Fecal grab samples were collected at 0630 and $1800 \mathrm{~h}$ from d 15 to 19 , and immediately frozen $\left(-20^{\circ} \mathrm{C}\right)$.

During the same days of fecal samples collection (d 15 to 19), samples of the mineral-vitamin and the concentrate mixes were collected, and pasture samples were plucked by hand twice daily after each milking to the approximate height to which cows grazed. Samples were dried at $55^{\circ} \mathrm{C}$ in a forced-air oven and ground through a 1-mm screen (Wiley Mill, Thomas Scientific, Philadelphia, PA). Mineral-vitamin mix and concentrate samples were composited by period, while handplucked pasture samples were composited by day. Composited mineral-vitamin mix, concentrate, and handplucked pasture samples were analyzed for DM, CP, and ash (AOAC, 1990), soluble CP (Krishnamoorthy et al., 1982), ADF and NDF (Ankom Daisy II, ANKOM Technology Corp., Fairport, NY), NSC (Smith, 1981; modified to use potassium ferricyanide as the colorimetric indicator), and in vitro DM digestibility (IVDMD,
Ankom Daisy II, ANKOM Technology Corp., Fairport, NY).

Fecal samples were thawed, dried at $55^{\circ} \mathrm{C}$ in a forced air oven, ground through a 1-mm screen (Wiley Mill, Thomas Scientific, Philadelphia, PA), and composited by cow for each period. Fecal samples were analyzed for CP (AOAC, 1990), ADF and NDF (Ankom Daisy II, ANKOM Technology Corp., Fairport, NY), and Cr (Kolver et al., 1998). Fecal Cr was used to calculate fecal output, and then pasture and total DMI as described by Kolver et al. (1998). Apparent digestibilities of DM, $\mathrm{NDF}$, and $\mathrm{CP}$ were determined with the fecal output estimated from $\mathrm{Cr}_{2} \mathrm{O}_{3}$ as a marker, the DMI, and the nutrient concentration in feces and feed.

Rumen fluid samples were collected from the four cannulated cows on d 20 at $0,4,8,12,16$, and $20 \mathrm{~h}$ beginning at $0530 \mathrm{~h}$. At 0 (0530) and $12 \mathrm{~h}$ (1730), cows were sampled indoors because these two sampling times coincided with the a.m. and p.m. milkings, respectively. At the other sampling times, cows were sampled in the pasture using a temporary construction made with mobile gates in the paddock. Rumen digesta samples were taken from the dorsal, ventral, and caudal area of the rumen, and squeezed through four layers of cheesecloth. The $\mathrm{pH}$ of the filtered ruminal fluid was measured immediately using a portable digital Cole Palmer $\mathrm{pH}$-meter, and a $15-\mathrm{ml}$ aliquot preserved with $3 \mathrm{ml}$ of $25 \%$ metaphosphoric acid and $3 \mathrm{ml}$ of $0.6 \% 2$ ethyl butyric acid (internal standard). These samples 
were stored at $-20^{\circ} \mathrm{C}$ and subsequently analyzed for $\mathrm{NH}_{3}-\mathrm{N}$ and VFA (Kolver et al., 1998).

The in situ technique was used to estimate ruminal disappearance of DM and NDF of pasture on the different treatments. Hand-plucked pasture samples were taken the day before the bags were incubated (d 19), cut into lengths of approximately $1 \mathrm{~cm}$, and placed in polyester bags (Marvelier White, Strauss Co., New York, NY) with a mean pore size of $52 \mu \mathrm{m}$ as described by Lykos and Varga (1995). Bags were incubated in the rumen of the four cannulated cows for $0,4,8,12,16$, 20,24 , and $48 \mathrm{~h}$ after being soaked in $39^{\circ} \mathrm{C}$ distilled water for $15 \mathrm{~min}$ beginning at $0530 \mathrm{~h}$ on $\mathrm{d} 20$. Bags were inserted in reverse order, and the $24,20,16,12$, 8 , and $4 \mathrm{~h}$ incubation times coincided with rumen fluid sampling times.

Blood samples were collected at $0630 \mathrm{~h}$ on d 14 (before the cows received the mineral-vitamin mix or concentrate) from the coccygeal vessels as described by Kolver and Muller (1998). Plasma was analyzed for glucose (Glucose kit no. 510, Sigma Chemical Co., St. Louis, MO), urea N (Stanbio Urea Nitrogen kit 580, Stanbio Laboratory, Inc., San Antonio, TX), and NEFA (Wako NEFA C-Kit no. 990-75401, Wako Chemicals USA, Inc., Richmond, VA).

Spot urine samples were taken by vulval stimulation after each milking on two consecutive days (d 14 and 15). Samples were acidified with $\mathrm{HCl}$ to maintain $\mathrm{pH}$ below 2 and stored at $-20^{\circ} \mathrm{C}$. Urine samples were thawed, a composited sample per cow was made for each period, and analyzed for allantoin (Chen, 1989) and creatinine (Sigma kit no. 555-A; Sigma Chemical Co.).

Between periods 2 and 3, when all cows were on a TMR diet, total urine was collected from eight cows (two of the five Latin squares), with the purpose of estimating daily creatinine excretion as an internal marker to estimate the total urine excretion (Valadares et al., 1999) during the grazing periods. Cows were kept and milked in metabolic stalls using individual portable milking units, and total urine was collected during four consecutive days with indwelling Folley catheters (24 French, 75-ml ballons) as described by Valadares et al. (1999). One mean daily creatinine excretion value $(\mathrm{mg} /$ $\mathrm{kg}$ of BW per day) was computed for each of the eight cows (Valadares et al., 1999). Total urine volume in grazing periods $1,2,3$, and 4 were estimated using the daily creatinine excretion value and the creatinine concentration in the spot urine samples taken in each period as: urine $(\mathrm{L} / \mathrm{d})=\mathrm{BW}$ (total creatinine excretion in $\mathrm{mg} / \mathrm{kg}$ of $\mathrm{BW}$ per $\mathrm{d} /$ creatinine concentration in the spot urine samples in $\mathrm{mg} / \mathrm{L}$; Valadares et al., 1999). Total urine in each of the periods was used to estimate the total excretion of $\mathrm{N}$ in urine and, together with the
$\mathrm{N}$ excretion in feces and milk, efficiency of $\mathrm{N}$ utilization was calculated.

Grazing behavior and ruminating time were measured in 16 cows from d 10 to 16 using automatic IGER behavior recorders (Rutter et al., 1997). Recorders were placed on one cow per treatment, twice daily after each milking and before cows were moved to the pasture. During the morning, recorders were placed on cows from 0730 to $1730 \mathrm{~h}(10 \mathrm{~h})$. Before the evening milking, recorders were removed from the cows to avoid damages during milking and feeding time and to download the information recorded during that period of time. During the night, recorders were placed on cows from 1830 to $0600 \mathrm{~h}$ (11 h $30 \mathrm{~min})$. Before the morning milking, recorders were removed and the information downloaded. The total time that the recorders were on the cows was $21 \mathrm{~h} 30 \mathrm{~min}$. Recorders were placed on cows during each of the four periods; however, because of equipment problems, no data were obtained during period 1. Data from periods 2,3 , and 4 were analyzed as a completed randomized experimental design with treatments as the only variable. A total final number of nine records per treatment was used in the analysis using the software IGER GRAZE (GRAZE User's Guide, documentation version 1.0, program version $0.74)$.

Milk production was recorded daily from d 11 to 21 during each period. Milk samples were collected three times (d 13, 16, and 19) and preserved with 2-bromo2-nitropropane-1,3 diol. Milk fat, total protein, and true protein were analyzed by infrared spectrophotometry (Foss 605B Milk-Scan; Foss Electric, Hillerod, Denmark) by the Pennsylvania DHIA milk testing laboratory.

Cows were weighed after evening milking on two consecutive days at the beginning (d 1 and 2 ) and at the end (d 20 and 21) of each period. On these days, body condition of the cows was scored by two experienced independent observers using the five-point BCS scale ( 1 = thin; 5 = fat).

\section{Statistical Analyses}

A total of 20 cows were initially assigned to the trial. One cow (rumen cannulated) on the treatment Low PA$\mathrm{U}$ was removed from the experiment during period 1 because of health problems not related to the treatment. One cow on treatments Low PA-U and High PA-U during periods 1 and 2, respectively, died after the end of the period 2. Before period 4, one cow assigned to treatment High PA-U was dried off because of advanced stage of lactation ( $>300 \mathrm{DIM})$. The final number of cows per treatment was 19 because of one missing cow during period 1 in treatment Low PA-U, one missing cow dur- 
ing period 3 in treatment Low PA-CS, one missing cow during period 4 in treatment High PA-CS, and one missing cow during period 4 in treatment High PA-U.

Performance data (intake, milk production, and milk composition) were analyzed as a $4 \times 4$ Latin square, replicated five times with a $2 \times 2$ factorial arrangement of treatments by the general linear model procedure of SAS (1999). The model included square, cow-withinsquare, period, main effect of PA, main effect of CS, interaction between PA and CS, plus the interactions between square and the other factors (square $\times$ period, square $\times \mathrm{PA}$, square $\times \mathrm{CS}$, and square $\times \mathrm{PA} \times \mathrm{CS})$. Both square and cow-within-square were considered random effects, while the others were considered fixed effects.

Rumen data (rumen fermentation and in situ data) were analyzed as a $4 \times 4$ Latin square with a $2 \times 2$ factorial arrangement of treatments by the general linear model procedure of SAS (1999). The model included cow, period, main effect of PA, main effect of CS, interaction between PA and CS, hour, plus the interactions between hour and the other factors $(\mathrm{h} \times \mathrm{cow}, \mathrm{h} \times$ period, $\mathrm{h} \times \mathrm{PA}, \mathrm{h} \times \mathrm{CS}$, and $\mathrm{h} \times \mathrm{PA} \times \mathrm{CS}$ ). Cow effect was considered random, while the others were considered fixed effects.

When significant $(P<0.05)$ effects due to dietary treatments were detected, mean separation was conducted by the PDIFF option in SAS (1999). All means presented are least squares means.

\section{RESULTS AND DISCUSSION}

\section{Weather Data}

Precipitation averaged 58, 45, 96, and $70 \mathrm{~mm}$ during periods 1 (May 10 to May 30), 2 (May 31 to June 20), 3 (September 3 to September 23), and 4 (September 24 to October 14), respectively. The precipitation during period 2 was $29 \mathrm{~mm}$ lower than the previous 10-yr average. Average high temperature was 22, 25, 23, and $18^{\circ} \mathrm{C}$, and average low temperature was $10,14,13$, and $8^{\circ} \mathrm{C}$ for periods $1,2,3$, and 4 , respectively. Both the average high and low temperatures in each period were similar to the previous 10-yr average. On average, day length during periods 1 and 2 was $14 \mathrm{~h} 41 \mathrm{~min}$, and during periods 3 and 4, $12 \mathrm{~h} 8 \mathrm{~min}$.

\section{Pasture Management and Quality}

Pasture management variables are presented in Table 2. The targeted PA for the low and high PA treatments were 25 and $40 \mathrm{~kg} \mathrm{DM} / \mathrm{cow}$ per day, respectively. Actual PA for the low and high PA treatments averaged 27 and $49 \mathrm{~kg} \mathrm{DM} / \mathrm{cow}$ per day, respectively $(P<0.05)$. The larger amount of pasture offered was provided by adjusting the paddock size (102 vs. $179 \mathrm{~m}^{2} /$ cow/d, for low and high PA, respectively), because the pregrazing pasture mass between pasture treatments did not differ and averaged $2761 \mathrm{~kg}$ of DM/ha $(P>0.05)$. Cows grazing at low PA had a lower average postgrazing pasture mass (1013 vs. $1575 \mathrm{~kg} \mathrm{DM} / \mathrm{ha} ; P<0.05$ ). The efficiency of harvesting, defined as pasture consumed/pasture offered, was significantly greater at low PA (62 vs. $42 \%$; $P<0.05$ ). Dalley et al. (1999) found decreased efficiency of pasture harvesting (from 54 to 26\%) when PA increased from 20 to $70 \mathrm{~kg} \mathrm{DM} / \mathrm{cow}$ per day, and pasture DMI reached a plateau of maximum intake at a PA of $55.2 \mathrm{~kg} \mathrm{DM} / \mathrm{cow}$ per day.

Pasture quality parameters (Table 2) correspond to hand-plucked pasture samples and represent the pasture selected by the cows. On average, pasture quality was $20 \% \mathrm{CP}, 15 \% \mathrm{NSC}$ and $56 \% \mathrm{NDF}$, and did not differ between low and high PA treatments. The high PA treatment had a higher IVDMD $(P<0.05)$ than the low $\mathrm{PA}$, and may be related to sampling errors. Pasture quality parameters were within the ranges summarized by Muller and Fales (1998) for cool-season grass during the spring and summer in Pennsylvania.

Significant period effects were detected for all parameters $(P<0.05)$, indicating that pasture quality varied among periods. When we compared the spring periods (periods 1 and 2) and the fall periods (periods 3 and 4), pasture had higher DM (26.9 vs. $16.1 \%$ ), NDF (59.4 vs. $51.9 \%$ ), and ADF (28.7 vs. $26.8 \%$ ), and lower NSC (13.9 vs. $15.5 \%)$ and IVDMD (70.7 vs. $72.6 \%)$ during the spring because spring pasture was grazed at a more advanced stage of maturity with the rapid pasture growth. These nutrient composition values are representative of the type of spring pastures in the northeast United States.

\section{Intake of Pasture and Substitution Rate}

Intake and apparent digestibility of nutrients are shown in Table 3. Dry matter intake of the mineralvitamin mix averaged $0.74 \mathrm{~kg} / \mathrm{d}$, and DMI of concentrate averaged $8.63 \mathrm{~kg} / \mathrm{d}$. A significant interaction between PA and CS was found for pasture and total DMI $(P<0.05)$. Concentrate supplementation decreased pasture DMI at both PA; however, the decrease in pasture DMI was higher when cows grazed at high versus low PA (4.4 vs. $2.0 \mathrm{~kg}$ of DM/d), indicating that the substitution rate was greater at the high PA. The substitution rate was 0.26 and $0.55 \mathrm{~kg}$ pasture/ $\mathrm{kg}$ concentrate at the low and high PA, respectively. Low substitution rates have been reported previously when cows grazed at low PA by Grainger and Mathews (1989), Meijs and Hoekstra (1984), Robaina et al. (1998), and Stakelum (1986). Summarizing these studies, at low PA (7.6 to $22.2 \mathrm{~kg} \mathrm{DM} / \mathrm{cow}$ per day), the substitution rate averaged 
Table 2. Pasture management and chemical composition of hand-plucked pasture samples of low and high pasture allowance treatments.

\begin{tabular}{|c|c|c|c|c|c|}
\hline & \multicolumn{2}{|c|}{ Treatments $^{1}$} & \multirow[b]{2}{*}{ SEM } & \multicolumn{2}{|c|}{$P<^{2}$} \\
\hline & Low PA & High PA & & $\mathrm{PA}$ & Period \\
\hline \multicolumn{6}{|l|}{ Pasture management } \\
\hline Pasture allowance, $\mathrm{kg} \mathrm{DM} /$ cow/d & 26.7 & 48.9 & 1.4 & $<0.01$ & 0.43 \\
\hline Area, $\mathrm{m}^{2} / \mathrm{cow} / \mathrm{d}$ & 102 & 179 & 5 & $<0.01$ & $<0.01$ \\
\hline Pregrazing herbage mass, $\mathrm{kg} \mathrm{DM} / \mathrm{ha}$ & 2712 & 2809 & 99 & 0.49 & $<0.01$ \\
\hline Postgrazing herbage mass, $\mathrm{kg} \mathrm{DM} / \mathrm{ha}$ & 1013 & 1575 & 43 & $<0.01$ & 0.01 \\
\hline Efficiency of harvesting, \% & 62 & 42 & 2 & $<0.01$ & 0.02 \\
\hline \multicolumn{6}{|l|}{ Chemical composition } \\
\hline $\begin{array}{l}\% \text { of DM } \\
\% \text { DM }\end{array}$ & 21.7 & 21.4 & 0.5 & 0.69 & $<0.01$ \\
\hline OM, \% & 92.0 & 92.2 & 0.1 & 0.28 & $<0.01$ \\
\hline $\mathrm{CP}, \%$ & 20.3 & 19.6 & 0.4 & 0.29 & $<0.01$ \\
\hline Soluble CP, \% & 4.8 & 4.7 & 0.3 & 0.81 & $<0.01$ \\
\hline $\mathrm{NSC}, \%$ & 14.2 & 15.3 & 0.3 & 0.03 & $<0.01$ \\
\hline NDF, $\%$ & 56.1 & 55.2 & 0.5 & 0.26 & $<0.01$ \\
\hline $\mathrm{ADF}, \%$ & 28.3 & 27.3 & 0.3 & 0.04 & $<0.01$ \\
\hline In vitro $\mathrm{DM}$ digestibility, $\%$ & 70.3 & 73.0 & 0.7 & 0.01 & 0.01 \\
\hline
\end{tabular}

$0.19 \mathrm{~kg}$ of pasture $/ \mathrm{kg}$ of concentrate (range from 0 to $0.31 \mathrm{~kg} / \mathrm{kg}$ ). At high PA (24 to $42.3 \mathrm{~kg} \mathrm{DM} /$ cow per day), the substitution rate averaged $0.58 \mathrm{~kg}$ of pasture $/ \mathrm{kg}$ of concentrate (range from 0.43 to $0.69 \mathrm{~kg} / \mathrm{kg}$ ).

The lower substitution rate at the low PA resulted in a greater increase in total DMI. Concentrate supplementation increased total DMI, but the increase was greater when cows grazed at low versus high PA (5.8 vs. $3.6 \mathrm{~kg} / \mathrm{d}$ ). Total DMI of both supplemented treatments did not differ $(24.4 \mathrm{~kg} / \mathrm{d} ; P>0.05)$. This number may be overestimated by the $\mathrm{Cr}_{2} \mathrm{O}_{3}$ method used to determine DMI. Holden et al. (1994) reported that using $\mathrm{Cr}_{2} \mathrm{O}_{3}$ as fecal marker overestimated DMI of silage and hay by $10 \%$ in comparison with DMI measured directly.

Apparent digestibility of DM was increased with supplementation, but the increase was higher at the low PA $(P<0.05$; Table 3$)$. This is in agreement with results of Reis and Combs (2000), who reported an increase in DM digestibility when cows were supplemented with 5 or $10 \mathrm{~kg} / \mathrm{d}$ of a corn-based concentrate. Apparent digestibility of CP was decreased with CS from 75.6 to $72.6 \%$ $(P<0.05)$, although it was not affected by PA $(P>0.05)$.

Intake of pasture and total diet NDF had a significant interaction between PA and CS $(P<0.05$; Table 3$)$. Concentrate supplementation reduced intake of pasture NDF by $1.2 \mathrm{~kg} / \mathrm{d}$ at low PA (9.9 vs. $8.7 \mathrm{~kg} / \mathrm{d})$ and $2.5 \mathrm{~kg} / \mathrm{d}$ at high PA $(11.5$ vs. $8.9 \mathrm{~kg} / \mathrm{d} ; P<0.05)$. Total intake of NDF was similar in both treatments that grazed at the low PA $(10.1 \mathrm{~kg} / \mathrm{d})$, but was reduced by $1.1 \mathrm{~kg} / \mathrm{d}$ with CS at the high PA $(P<0.05)$. Total NDF expressed as a percentage of dietary DM averaged $54.7 \%$ (54\% from the forage) in the unsupplemented treatments and averaged $42.2 \%$ (36.1\% from the forage) in the supplemented treatments. These values exceed those recommended as minimums for high producing dairy cows fed TMR diets (NRC, 2001). At the low PA, CS slightly reduced the apparent digestibility of NDF (1.1 percentage points) while at the high $\mathrm{PA}$, the reduction in apparent digestibility of NDF was 4.3 percentage points $(P<0.05)$. This suggests a negative associative effect with CS, and may explain some of the different rate of substitution between the low and the high PA.

Total intake of $\mathrm{NE}_{\mathrm{L}}$ (Table 3) was increased significantly by CS; however, the increase was greater at the low PA than at the high PA (11.4 vs. $7.7 \mathrm{Mcal} / \mathrm{d})$. This was a result of an increase in $14.8 \mathrm{Mcal} / \mathrm{d}$ of $\mathrm{NE}_{\mathrm{L}}$ from CS because pasture $\mathrm{NE}_{\mathrm{L}}$ intake was reduced by supplementation (3.3 vs. $7.3 \mathrm{Mcal} / \mathrm{d}$ at the low and high PA, respectively). Total intake of $\mathrm{NE}_{\mathrm{L}}$ in both supplemented treatments averaged $41.6 \mathrm{Mcal} / \mathrm{d}$. The total diet composition averaged $19.5 \% \mathrm{CP}, 54.7 \% \mathrm{NDF}, 27.2 \% \mathrm{ADF}$, and $1.63 \mathrm{Mcal} / \mathrm{kg} \mathrm{DM}$ of $\mathrm{NE}_{\mathrm{L}}$ for the two unsupplemented treatments, and $17.7 \% \mathrm{CP}, 42.2 \% \mathrm{NDF}, 20.2 \% \mathrm{ADF}$, and $1.70 \mathrm{Mcal} / \mathrm{kg} \mathrm{DM}$ of $\mathrm{NE}_{\mathrm{L}}$ for the two supplemented treatments (Table 3).

\section{Milk Production and Milk Composition}

A significant interaction was found for milk and 3.5\% FCM production between PA and CS $(P<0.05$; Table 4$)$. Supplementation increased milk production; however, the increase was greater when cows grazed at the low versus high $\mathrm{PA}(10.6 \mathrm{vs} .7 .7 \mathrm{~kg} / \mathrm{d})$. The $\mathrm{PA} \times \mathrm{CS}$ interaction for milk production is consistent with the interac- 
Table 3. Intake and apparent digestibility of $\mathrm{DM}, \mathrm{CP}$, and $\mathrm{NDF}$, and intake of $\mathrm{NE}_{\mathrm{L}}$ of unsupplemented or supplemented dairy cows grazing at two pasture allowances.

\begin{tabular}{|c|c|c|c|c|c|c|c|c|}
\hline & \multicolumn{2}{|c|}{ Low $\mathrm{PA}^{1}$} & \multicolumn{2}{|c|}{ High $\mathrm{PA}^{2}$} & \multirow[b]{2}{*}{ SEM } & \multicolumn{3}{|c|}{$P<<^{3}$} \\
\hline & $\mathrm{U}$ & $\mathrm{CS}$ & $\mathrm{U}$ & CS & & $\mathrm{CS}$ & PA & $\mathrm{CS} \times \mathrm{PA}$ \\
\hline \multicolumn{9}{|l|}{ DMI, kg/d } \\
\hline Supplement & 0.8 & 8.6 & 0.7 & 8.7 & 0.1 & $<0.01$ & 0.56 & 0.36 \\
\hline Pasture & 17.5 & 15.5 & 20.5 & 16.1 & 0.4 & $<0.01$ & $<0.01$ & 0.01 \\
\hline Total & 18.3 & 24.1 & 21.2 & 24.8 & 0.4 & $<0.01$ & $<0.01$ & 0.01 \\
\hline Total, \% of BW & 2.91 & 3.85 & 3.37 & 3.97 & 0.06 & $<0.01$ & $<0.01$ & 0.01 \\
\hline $\mathrm{DM} \mathrm{AD},{ }^{4} \%$ & 66.2 & 70.9 & 70.2 & 70.9 & 0.3 & $<0.01$ & $<0.01$ & $<0.01$ \\
\hline \multicolumn{9}{|l|}{$\mathrm{CP}$ intake, $\mathrm{kg} / \mathrm{d}$} \\
\hline Supplement & 0.1 & 1.1 & 0.1 & 1.1 & 0.01 & $<0.01$ & 0.64 & 0.40 \\
\hline Pasture & 3.5 & 3.2 & 4.0 & 3.2 & 0.1 & 0.02 & 0.01 & $<0.01$ \\
\hline Total & 3.6 & 4.3 & 4.1 & 4.3 & 0.1 & 0.03 & 0.01 & $<0.01$ \\
\hline $\mathrm{CP} \mathrm{AD},{ }^{4} \%$ & 74.4 & 72.9 & 76.7 & 72.3 & 0.6 & $<0.01$ & 0.11 & 0.09 \\
\hline \multicolumn{9}{|l|}{ NDF intake, kg/d } \\
\hline Supplement & 0.2 & 1.5 & 0.1 & 1.5 & 0.02 & $<0.01$ & 0.68 & 0.27 \\
\hline Pasture & 9.9 & 8.7 & 11.4 & 8.9 & 0.2 & $<0.01$ & $<0.01$ & $<0.01$ \\
\hline Total & 10.1 & 10.2 & 11.5 & 10.4 & 0.2 & 0.03 & $<0.01$ & $<0.01$ \\
\hline Total, \% of BW & 1.61 & 1.65 & 1.83 & 1.68 & 0.03 & 0.01 & $<0.01$ & $<0.01$ \\
\hline Forage, $\%$ of $\mathrm{BW}$ & 1.59 & 1.41 & 1.81 & 1.44 & 0.03 & $<0.01$ & $<0.01$ & $<0.01$ \\
\hline $\mathrm{NDF} A D,{ }^{4} \%$ & 66.2 & 65.1 & 70.4 & 66.1 & 0.5 & 0.01 & $<0.01$ & $<0.01$ \\
\hline \multicolumn{9}{|l|}{$\mathrm{NE}_{\mathrm{L}}$ intake,${ }^{5} \mathrm{Mcal} / \mathrm{d}$} \\
\hline Supplement & 0.7 & 15.4 & 0.7 & 15.7 & 0.2 & $<0.01$ & 0.47 & 0.42 \\
\hline Pasture & 28.9 & 25.6 & 33.9 & 26.6 & 0.7 & $<0.01$ & $<0.01$ & $<0.01$ \\
\hline Total & 29.6 & 41.0 & 34.6 & 42.3 & 0.7 & $<0.01$ & $<0.01$ & $<0.01$ \\
\hline \multicolumn{9}{|l|}{ Total diet, \% } \\
\hline $\mathrm{CP}$ & 19.7 & 17.9 & 19.3 & 17.5 & 0.11 & $<0.01$ & $<0.01$ & 0.51 \\
\hline $\mathrm{NDF}$ & 55.2 & 42.3 & 54.2 & 41.9 & 0.29 & $<0.01$ & 0.15 & 0.83 \\
\hline $\mathrm{ADF}$ & 27.5 & 20.5 & 26.8 & 19.9 & 0.14 & $<0.01$ & $<0.01$ & 0.69 \\
\hline $\mathrm{NE}_{\mathrm{L}}, \mathrm{Mcal} / \mathrm{kg}$ & 1.62 & 1.70 & 1.63 & 1.70 & 0.001 & $<0.01$ & 0.02 & 0.02 \\
\hline \multicolumn{9}{|c|}{$\begin{array}{l}{ }^{1} \text { Low PA-U = Low pasture allowance-unsupplemented, Low PA-CS = low pasture allowance-concentrate } \\
\text { supplementation. }\end{array}$} \\
\hline \multicolumn{9}{|c|}{$\begin{array}{l}{ }^{2} \text { High PA-U = High pasture allowance- unsupplemented, High PA-CS = high pasture allowance-concen- } \\
\text { trate supplementation. }\end{array}$} \\
\hline \\
\hline \multicolumn{9}{|c|}{ Concentrate supplementation by pasture allowance interaction. } \\
\hline \multicolumn{9}{|c|}{${ }^{4} \mathrm{AD}=$ Total tract apparent digestibility. } \\
\hline $\begin{array}{l}{ }^{5} \text { Calculated usin } \\
1.80 \text {, and } 1.65 \mathrm{Mca}\end{array}$ & C (198s & $\mathrm{JE}_{\mathrm{L}}$ val & & & & & & \\
\hline
\end{tabular}

tion between PA and CS found for total DMI. Because of this interaction, milk response to CS was greater when cows grazed at low versus high PA (1.36 vs. 0.96 $\mathrm{kg}$ of milk/kg of concentrate). Previous studies have reported higher milk responses to CS for cows grazing at low PA compared to higher PA (Grainger and Mathews, 1989; Robaina et al., 1998; Stakelum, 1986). Summarizing these studies, at low PA (mean $15.5 \mathrm{~kg}$ of $\mathrm{DM} /$ cow per day; range: 7.6 to $21.1 \mathrm{~kg} \mathrm{DM} /$ cow per day) the response to supplementation averaged $0.81 \mathrm{~kg}$ of milk/ $\mathrm{kg}$ of concentrate (range: 0.61 to $0.98 \mathrm{~kg}$ of milk/ $\mathrm{kg}$ of concentrate). At high PA (mean $33.3 \mathrm{~kg}$ of DM/ cow per day; range: 24 to $42.3 \mathrm{~kg}$ of $\mathrm{DM} / \mathrm{cow}$ per day) the response to supplementation averaged $0.35 \mathrm{~kg}$ of milk/kg of concentrate.

In our study, the milk response to CS at both low and high PA was higher (0.96 and $1.36 \mathrm{~kg}$ of milk/ $\mathrm{kg}$ of concentrate, respectively) than in those studies.
Kellaway and Porta (1993) summarized grazing studies conducted with low producing dairy cows and reported an average milk response to CS of $0.6 \mathrm{~kg}$ of milk/kg of concentrate when pasture was restricted, and no response when high quality pasture was available ad libitum. The higher milk responses found in our study are likely related to the high genetic merit and milk production of the Holstein cows used and also to the medium quality of the pasture grazed (Table 2). Stockdale (1999) reported that milk responses to CS supplementation increased as content of metabolizable energy of pasture decreased. Grazing studies conducted in the United States with high producing dairy cows (Reis and Combs, 2000) reported a response of 1.00 and $0.86 \mathrm{~kg}$ of milk/kg of concentrate when cows grazing an alfalfaryegrass pasture were supplemented with 5 or $10 \mathrm{~kg} /$ $\mathrm{d}$ of a corn-based concentrate, respectively. A recent study from Europe (Delaby et al., 2001) reported high 
Table 4. Milk production and composition of unsupplemented or supplemented dairy cows grazing at two pasture allowances.

\begin{tabular}{|c|c|c|c|c|c|c|c|c|}
\hline & \multicolumn{2}{|c|}{ Low $\mathrm{PA}^{1}$} & \multicolumn{2}{|c|}{ High $\mathrm{PA}^{2}$} & \multirow[b]{2}{*}{ SEM } & \multicolumn{3}{|c|}{$P<^{3}$} \\
\hline & $\mathrm{U}$ & $\mathrm{CS}$ & $\mathrm{U}$ & CS & & CS & PA & $\mathrm{CS} \times \mathrm{PA}$ \\
\hline Milk, kg/d & 19.1 & 29.7 & 22.2 & 29.9 & 0.8 & $<0.01$ & 0.04 & 0.03 \\
\hline $3.5 \%$ FCM, kg/d & 20.3 & 28.4 & 23.3 & 28.9 & 0.9 & $<0.01$ & 0.05 & 0.05 \\
\hline \multicolumn{9}{|l|}{ Fat } \\
\hline$\%$ & 3.82 & 3.29 & 3.79 & 3.32 & 0.07 & $<0.01$ & 0.96 & 0.53 \\
\hline $\mathrm{kg} / \mathrm{d}$ & 0.74 & 0.96 & 0.84 & 0.98 & 0.04 & 0.01 & 0.08 & 0.01 \\
\hline \multicolumn{9}{|l|}{ Total protein (TP) } \\
\hline$\%$ & 2.98 & 3.08 & 2.93 & 3.11 & 0.04 & $<0.01$ & 0.71 & 0.27 \\
\hline $\mathrm{kg} / \mathrm{d}$ & 0.55 & 0.89 & 0.64 & 0.90 & 0.02 & $<0.01$ & 0.03 & 0.05 \\
\hline \multicolumn{9}{|l|}{ True protein } \\
\hline$\%$ & 2.76 & 2.89 & 2.73 & 2.92 & 0.04 & $<0.01$ & 0.98 & 0.42 \\
\hline $\mathrm{kg} / \mathrm{d}$ & 0.50 & 0.83 & 0.59 & 0.84 & 0.02 & $<0.01$ & 0.03 & 0.05 \\
\hline $\mathrm{MUN},{ }^{4} \mathrm{mg} / \mathrm{dl}$ & 13.9 & 11.6 & 14.2 & 11.1 & 0.4 & $<0.01$ & 0.74 & 0.49 \\
\hline \multicolumn{9}{|l|}{$\mathrm{N}$ fractions, $\%$} \\
\hline TP/TP & 92 & 94 & 93 & 94 & 0.3 & 0.01 & 0.12 & 0.20 \\
\hline NPN/TP & 8 & 6 & 7 & 6 & 0.3 & 0.01 & 0.12 & 0.20 \\
\hline MUN/TP & 5 & 4 & 5 & 4 & 0.1 & $<0.01$ & 0.93 & 0.36 \\
\hline MUN/NPN & 70 & 65 & 76 & 61 & 2.8 & 0.01 & 0.81 & 0.24 \\
\hline
\end{tabular}

\footnotetext{
${ }^{1}$ Low PA-U = Low pasture allowance-unsupplemented, Low PA-CS = low pasture allowance-concentrate supplementation.

${ }^{2}$ High PA-U = High pasture allowance—unsupplemented, High PA-CS = high pasture allowance—concentrate supplementation.

${ }^{3} \mathrm{CS}=$ Main effect of concentrate supplementation, $\mathrm{PA}=$ main effect of pasture allowance, $\mathrm{CS} \times \mathrm{PA}=$ Concentrate supplementation by pasture allowance interaction.

${ }^{4} \mathrm{MUN}=$ Milk urea nitrogen.
}

milk responses (from 0.82 to $1.14 \mathrm{~kg} / \mathrm{kg}$ of concentrate) to CS (from 0 to $5.4 \mathrm{~kg} / \mathrm{d}$ ) when high producing dairy cows grazed a ryegrass pasture at different PA (from 12 to $22 \mathrm{~kg}$ of DM/cow per day, measured at $5 \mathrm{~cm}$ cutting height). In that study, however, the interaction between CS and PA (i.e., higher milk response at low PA) was not as clear as it was in our study.

Significant period effects were found for milk production $(P<0.05)$. However, milk production among periods is confounded by different stages of lactation and quality of pasture, especially when comparing the spring periods to the fall periods due to the Latin square design used in this study. During periods 1 and 2 (spring periods), milk production averaged 24.2 and $34.9 \mathrm{~kg} / \mathrm{d}$ for the unsupplemented and supplemented cows at the low $\mathrm{PA}$, respectively; and 25.7 and $35.4 \mathrm{~kg} / \mathrm{d}$ for the unsupplemented and supplemented cows at the high PA, respectively. The slight difference between the unsupplemented cows at low and high PA (1.5 kg of milk/d) may be attributed to higher mobilization of body reserves to maintain this milk production level, therefore buffering the difference between these two treatments. During periods 3 and 4 (fall periods), milk production averaged 15.2 and $23.7 \mathrm{~kg} / \mathrm{d}$ for unsupplemented and supplemented cows at the low PA, and 18.9 and $24.5 \mathrm{~kg} / \mathrm{d}$ for unsupplemented and supplemented cows at the high $\mathrm{PA}$, respectively. Comparing the milk production be- tween unsupplemented and supplemented cows in the spring and fall periods, the smaller difference observed during the spring compared with the fall at both PA may be related to a higher mobilization of body reserves at the earlier stage of lactation.

Concentrate supplementation reduced milk fat percentage in milk at both PA (3.81 vs. $3.31 \% ; P<0.05)$ but increased milk fat yield $(P<0.05$; Table 4$)$. The reduction in milk fat percentage is in agreement with other grazing studies where cows were supplemented with greater than $5 \mathrm{~kg} / \mathrm{cow}$ per day (Arriaga-Jordan and Holmes, 1986; Reis and Combs, 2000; Delaby et al., 2001). Arriaga-Jordan and Holmes (1986) reported a decrease in milk fat content from 3.73 to $3.51 \%$ when cows were supplemented with 1 or $6 \mathrm{~kg} / \mathrm{d}$ of a barleybased concentrate. Studies with high producing dairy cows showed linear reductions in milk fat content with a linear increase in CS: 0,5 , and $10 \mathrm{~kg} / \mathrm{d}$ (Reis and Combs, 2000), and 0, 3, and $6 \mathrm{~kg} / \mathrm{d}$ or 0, 2, 4, and $6 \mathrm{~kg} /$ d (Delaby et al., 2001). Sayers (1999) also a reported reduction in milk fat from 3.66 to $2.99 \%$ with high producing dairy cows grazing ryegrass pasture when the supplementation was increased from 5 to $10 \mathrm{~kg} / \mathrm{d}$.

Concentrate supplementation increased the total protein and true protein percentage in milk, and the milk protein yield at both PA $(P<0.05$; Table 4$)$. The increase in both total and true protein is likely related 
to the higher total energy intake (Table 3 ) in the supplemented cows. Total protein in unsupplemented and supplemented cows averaged 2.96 and $3.10 \%$, respectively. Previous grazing studies have shown that CS increased milk protein (Petch et al., 1997; Sayers, 1999; Reis and Combs, 2000). Supplementation with $5 \mathrm{~kg} / \mathrm{d}$ of cereal concentrate increased total and true protein in dairy cows grazing at a PA of $23 \mathrm{~kg} \mathrm{DM} /$ cow per day (Petch et al., 1997). Increasing the CS from 5 to $10 \mathrm{~kg} /$ $\mathrm{d}$ increased milk protein from 3.37 to $3.55 \%$ with cows grazing ryegrass pasture (Sayers, 1999). Milk protein percentage was linearly increased $(2.85,2.95$, and $3.05 \%$ ) with 0,5 , or $10 \mathrm{~kg} / \mathrm{d}$ of a corn-based concentrate with alfalfa-ryegrass pasture (Reis and Combs, 2000). Delaby et al. (2001) also reported a linear increase in milk protein with linear increase in CS for dairy cows grazing at different PA.

Concentrate supplementation reduced milk urea nitrogen (MUN) concentration regardless of the PA (14.1 vs. $11.3 \mathrm{mg} / \mathrm{dl} ; P<0.05$; Table 4 ). This is in agreement with Reis and Combs (2000) who reported a linear reduction in MUN (20.2, 16.9, and $13.4 \mathrm{mg} / \mathrm{dl}$ ) in cows supplemented with 0,5 , or $10 \mathrm{~kg} / \mathrm{d}$ of a corn-based concentrate. The lower MUN values in the unsupplemented cows reported in our study than those reported by Reis and Combs (2000) may be related to a grass pasture compared to a pasture including alfalfa. Cows consuming a direct-cut grass-legume forage had a lower MUN concentration (10.0 vs. $14.7 \mathrm{mg} / \mathrm{dl}$ ) when fed 10 $\mathrm{kg} / \mathrm{d}$ of dry or high moisture corn compared with no supplementation (Reis et al., 2001). Supplementation increased the proportion of true protein over total protein and reduced the proportion of NPN and MUN in total protein $(P<0.05$; Table 4$)$. A previous study where cows grazed at a PA of $23 \mathrm{~kg} \mathrm{DM} / \mathrm{cow}$ per day reported a lower NPN and MUN in milk when supplemented with $5 \mathrm{~kg} / \mathrm{d}$ of concentrate (Petch et al., 1997).

\section{Body Weight, Body Condition Score, and Blood and Urine Metabolites}

Neither initial nor final BW and BCS were affected by treatments $(P>0.05)$. For all cows, the initial and final BW averaged 634 and $632 \mathrm{~kg}$, respectively; and initial and final BCS averaged 2.73 and 2.66, respectively. A loss of BW and BCS was expected during the first two periods for the unsupplemented cows; however, the Latin square design may have disguised differences among treatments.

Short-term indicators such as NEFA concentrations are useful to make inferences on changes in body reserves. Unsupplemented cows had higher plasma concentrations of NEFA than supplemented cows at both PA (344 vs. $263 \mu \mathrm{eq} / \mathrm{L} ; P<0.05$; Table 5). This indicates a higher body fat mobilization especially during early lactation (periods 1 and 2), which may explain differences in milk production among periods. The smaller difference in milk production between unsupplemented and supplemented cows during the spring may be associated with a higher mobilization of body fat in early lactation cows. Unsupplemented cows grazing at the low PA had the highest numerical NEFA concentrations $(380 \mu \mathrm{eq} / \mathrm{L})$, which agree with the slight difference in milk production between unsupplemented cows at low and high PA during periods 1 and 2, as discussed previously. The higher NEFA concentrations in the unsupplemented cows suggest higher mobilization of fat reserves in comparison with the supplemented cows.

Concentrate supplementation decreased plasma urea nitrogen (PUN) at both PA (16.1 vs. $12.5 \mathrm{mg} / \mathrm{dl} ; P<$ 0.05; Table 5). These results are consistent with the reduction in MUN concentration, suggesting that supplementation improved the efficiency of dietary $\mathrm{N}$ utilization. Concentrate supplementation increased plasma glucose concentration at both PA (66.7 vs. $62.9 \mathrm{mg} / \mathrm{dl}$; $P<0.05)$. Although this difference was significant, the glucose concentration in unsupplemented cows was within normal physiological levels (45 to $70 \mathrm{mg} / \mathrm{dl}$ ). Opatpatanakit et al. (1993) reported increased glucose concentrations with supplementation of 0,4 , and $8 \mathrm{~kg} /$ $\mathrm{d}$ of barley to cows grazing a ryegrass-white clover pasture, although these differences $(65.0,68.1$, and 68.5 $\mathrm{mg} / \mathrm{dl}$ ) were not significant.

The concentrations of purine derivatives (allantoin, uric acid, xanthine, and hypoxanthine) in urine have been proposed as a noninvasive method to estimate the microbial protein flow to the duodenum in intact animals (Gonda, 1995). Among the purine derivatives, allantoin is the most important in cattle and is excreted at a constant proportion to the other purine derivatives. Therefore, the allantoin concentration can be used to estimate rumen microbial protein (Gonda, 1995). Creatinine, the end product of phosphocreatinine degradation, can be used as an internal marker to predict metabolic processes in intact animals. Urinary excretion of creatinine is not affected by energy or protein intake changes and is excreted in proportion to BW (Gonda, 1995). The allantoin/creatinine ratio in spot urine samples was constant during the day and followed the same trend as allantoin excretion in urine, supporting the idea that allantoin/creatinine ratio could be used as an index of total allantoin excretion in urine, and, therefore, avoiding the total collection of urine (Gonda, 1995).

A PA $\times$ CS interaction was found for allantoin concentration in urine spot samples $(P<0.05$; Table 5$)$. Concentrate supplementation increased the allantoin concentration in urine spot samples, but the increase was higher at low PA (1414 vs. $1878 \mathrm{mg} / \mathrm{L}$ ), compared with 
Table 5. Blood and urine metabolites of unsupplemented or supplemented dairy cows grazing at two pasture allowances.

\begin{tabular}{|c|c|c|c|c|c|c|c|c|}
\hline & \multicolumn{2}{|c|}{ Low $\mathrm{PA}^{1}$} & \multicolumn{2}{|c|}{ High $\mathrm{PA}^{2}$} & \multirow[b]{2}{*}{ SEM } & \multicolumn{3}{|c|}{$P<<^{3}$} \\
\hline & $\mathrm{U}$ & CS & $\mathrm{U}$ & CS & & CS & PA & $\mathrm{CS} \times \mathrm{PA}$ \\
\hline \multicolumn{9}{|l|}{ Blood } \\
\hline NEFA, $\mu \mathrm{eq} / \mathrm{L}$ & 380.4 & 282.5 & 308.2 & 243.7 & 22.3 & $<0.01$ & 0.02 & 0.45 \\
\hline $\mathrm{PUN},{ }^{4} \mathrm{mg} / \mathrm{dl}$ & 16.4 & 12.5 & 15.7 & 12.5 & 0.4 & $<0.01$ & 0.38 & 0.45 \\
\hline Glucose,mg/dl & 63.0 & 65.8 & 62.8 & 67.7 & 1.1 & $<0.01$ & 0.40 & 0.34 \\
\hline \multicolumn{9}{|l|}{ Urine } \\
\hline Allantoin (A), mg/L & 1414 & 1878 & 1617 & 1908 & 41 & $<0.01$ & 0.01 & 0.05 \\
\hline Creatinine $(\mathrm{C}), \mathrm{mg} / \mathrm{L}$ & 505 & 585 & 524 & 587 & 18 & $<0.01$ & 0.57 & 0.64 \\
\hline $\mathrm{A} / \mathrm{C}$ ratio & 2.89 & 3.26 & 3.17 & 3.35 & 0.11 & 0.02 & 0.09 & 0.39 \\
\hline
\end{tabular}

\footnotetext{
${ }^{1}$ Low PA-U = Low pasture allowance-unsupplemented, Low PA-CS = low pasture allowance—concentrate supplementation.

${ }^{2}$ High PA-U = High pasture allowance-unsupplemented, High PA-CS = high pasture allowance—concentrate supplementation.

${ }^{3} \mathrm{CS}=$ Main effect of concentrate supplementation, $\mathrm{PA}=$ main effect of pasture allowance, $\mathrm{CS} \times \mathrm{PA}=$ concentrate supplementation by pasture allowance interaction.

${ }^{4} \mathrm{PUN}=$ Plasma urea nitrogen.
}

the higher PA (1617 vs. 1908 mg/L). Creatinine concentration in urine spot samples was increased by CS at both PA $(P<0.05$; Table 5). Similarly, the allantoin/ creatinine ratio in spot samples of urine was increased by CS at both PA $(P<0.05$; Table 5$)$, indicating that CS increased rumen microbial protein supply. These results are in agreement with the increased allantoin/ creatinine ratio reported by Reis et al. (2001) with corn supplementation in high producing dairy cows fed direct-cut grass-legume forage.

\section{Ruminal Fermentation}

A significant PA $\times$ CS interaction was detected for rumen $\mathrm{pH}(P<0.05$; Table 6$)$. Concentrate supplementation reduced rumen $\mathrm{pH}$; however, the reduction was greater at the low $\mathrm{PA}(6.57$ vs. 6.25$)$ compared with the high PA $(6.40$ vs. $6.29 ; P<0.05)$. The high rumen $\mathrm{pH}$ observed in the unsupplemented cows is likely related to the medium quality of pasture grazed (Table 2). Both supplemented groups had similar rumen $\mathrm{pH}$ (average $6.27 ; P>0.05$ ). Previous grazing studies have reported no modification in rumen $\mathrm{pH}$ with medium (Van $\mathrm{Vu}$ uren, 1993) or high (Reis and Combs, 2000) levels of CS. In agreement with our study, rumen $\mathrm{pH}$ decreased as concentrate increased from 5 to $10 \mathrm{~kg} / \mathrm{d}$ in dairy cows grazing a ryegrass pasture (Sayers, 1999).

Ruminal $\mathrm{pH}$ oscillation at 4-h intervals during a 24$\mathrm{h}$ period is shown in Figure 1. Unsupplemented cows grazing at low PA (Low PA-U) had higher $\mathrm{pH}$ throughout the day, especially during the morning. Unsupplemented cows grazing at high PA (High PA-U) had intermediate $\mathrm{pH}$ values that were lower than unsupplemented cows grazing at low PA but higher than both supplemented treatments, indicating the interaction between PA and CS for the mean daily values (Table 6). Both supplemented groups had the lowest rumen $\mathrm{pH}$ values during the $24 \mathrm{~h}$, which did not differ between PA (Low PA-CS and High PA-CS). The pattern of rumen $\mathrm{pH}$ variations differed between the unsupplemented and supplemented treatments. Both supplemented treatments had the same pattern with important reductions in rumen $\mathrm{pH}$ after cows were fed concentrate and initiated grazing. The highest rumen $\mathrm{pH}$ values in supplemented cows were found after the periods of lower grazing activity at $1330 \mathrm{~h}$ and between 0130 and 0530 h. Unsupplemented cows had lower rumen $\mathrm{pH}$ at 1730 $\mathrm{h}$, probably because of differences in grazing behavior patterns.

Concentrate supplementation reduced significantly the concentration of $\mathrm{NH}_{3}-\mathrm{N}$ at both $\mathrm{PA}$ ( $15.3 \mathrm{vs.} 8.9 \mathrm{mg} /$ dl; $P<0.05$; Table 6). The reduction in rumen $\mathrm{NH}_{3}-\mathrm{N}$ concentration with supplementation is consistent with the reductions in PUN and MUN, and with other research (Reis and Combs, 2000; Reis et al., 2001; Van Vuuren, 1993). Reis and Combs (2000) reported a linear decrease in rumen $\mathrm{NH}_{3}-\mathrm{N}(22.4,17.7$, and $8.1 \mathrm{mg} / \mathrm{dl})$ for supplementation levels of 0,5 , or $10 \mathrm{~kg} / \mathrm{d}$ with high producing cows. The reduction in rumen $\mathrm{NH}_{3}-\mathrm{N}$ with CS is likely associated with an improved utilization of $\mathrm{NH}_{3}-\mathrm{N}$ as a result of the high rumen degradability of pasture proteins or to a reduction in total CP intake because energy supplements are lower in $\mathrm{CP}$ than pasture. The reduction in rumen $\mathrm{NH}_{3}-\mathrm{N}$ concentration in our study is likely related to a higher utilization of $\mathrm{NH}_{3}-$ $\mathrm{N}$ because microbial protein synthesis was increased (higher allantoin/creatinine ratio; Table 5), and total CP intake was not reduced with supplementation (Table 3 ). This suggests a higher efficiency in dietary protein utilization in both supplemented treatments. 
Table 6. Ruminal fermentation parameters and rumen content characteristics of unsupplemented or supplemented dairy cows grazing at two pasture allowances.

\begin{tabular}{|c|c|c|c|c|c|c|c|c|}
\hline & \multicolumn{2}{|c|}{ Low $\mathrm{PA}^{1}$} & \multicolumn{2}{|c|}{ High $\mathrm{PA}^{2}$} & \multirow[b]{2}{*}{ SEM } & \multicolumn{3}{|c|}{$P<^{3}$} \\
\hline & $\mathrm{U}$ & CS & $\mathrm{U}$ & CS & & CS & $\mathrm{PA}$ & $\mathrm{CS} \times \mathrm{PA}$ \\
\hline $\mathrm{pH}$ & 6.57 & 6.25 & 6.40 & 6.29 & 0.04 & $<0.01$ & 0.14 & 0.03 \\
\hline $\mathrm{NH}_{3}-\mathrm{N}, \mathrm{mg} / \mathrm{dl}$ & 15.22 & 9.14 & 15.33 & 8.71 & 0.54 & $<0.01$ & 0.79 & 0.64 \\
\hline \multicolumn{9}{|l|}{$\mathrm{VFA}, \mathrm{mmol} / \mathrm{L}$} \\
\hline Total & 116.3 & 130.0 & 129.8 & 130.6 & 2.3 & 0.01 & 0.01 & 0.02 \\
\hline Acetate (A) & 79.3 & 85.1 & 88.9 & 84.9 & 1.5 & 0.55 & 0.01 & 0.01 \\
\hline Propionate $(\mathrm{P})$ & 22.3 & 25.6 & 24.1 & 26.2 & 0.6 & $<0.01$ & 0.08 & 0.38 \\
\hline Butyrate & 10.7 & 14.8 & 12.5 & 15.1 & 0.4 & $<0.01$ & 0.03 & 0.13 \\
\hline Isobutyrate & 1.2 & 1.1 & 1.2 & 1.0 & 0.03 & $<0.01$ & 0.74 & 0.68 \\
\hline Valerate & 1.5 & 1.9 & 1.7 & 1.9 & 0.04 & $<0.01$ & 0.02 & 0.14 \\
\hline Isovalerate & 1.3 & 1.5 & 1.4 & 1.4 & 0.1 & 0.15 & 0.42 & 0.01 \\
\hline $\mathrm{A} / \mathrm{P}$ & 3.6 & 3.4 & 3.7 & 3.3 & 0.1 & $<0.01$ & 0.68 & 0.02 \\
\hline \multicolumn{9}{|l|}{ Rumen content } \\
\hline Volume, L & 97.2 & 95.6 & 108.2 & 100.3 & 5.7 & 0.48 & 0.26 & 0.63 \\
\hline Wet fill, $\mathrm{kg}$ & 80.6 & 79.4 & 89.8 & 83.3 & 4.7 & 0.48 & 0.26 & 0.63 \\
\hline Dry fill, kg DM & 9.8 & 12.0 & 11.8 & 12.4 & 0.6 & 0.08 & 0.11 & 0.24 \\
\hline DM content, \% & 12.0 & 14.5 & 13.0 & 13.9 & 0.4 & 0.01 & 0.69 & 0.12 \\
\hline $\mathrm{DR},{ }^{4} \% / \mathrm{h}$ & 9.9 & 12.6 & 9.8 & 12.7 & 1.9 & 0.23 & 0.99 & 0.97 \\
\hline Retention time ${ }^{5} \mathrm{~h}$ & 14.1 & 12.2 & 13.9 & 12.7 & 0.8 & 0.14 & 0.86 & 0.69 \\
\hline
\end{tabular}

\footnotetext{
${ }^{1}$ Low PA-U = Low pasture allowance-unsupplemented, Low PA-CS = low pasture allowance-concentrate supplementation.

${ }^{2}$ High PA-U = High pasture allowance-unsupplemented, High PA-CS = high pasture allowance-concentrate supplementation.

${ }^{3} \mathrm{CS}=$ Main effect of concentrate supplementation, $\mathrm{PA}=$ main effect of pasture allowance, $\mathrm{CS} \times \mathrm{PA}=$ concentrate supplementation by pasture allowance interaction.

${ }^{4}$ Disappearance rate $=(\mathrm{DMI} / 24 \mathrm{~h}) /$ dry fill.

${ }^{5}$ Retention time $=$ dry fill/(DMI/24 h).
}

Rumen $\mathrm{NH}_{3}-\mathrm{N}$ concentrations during a 24-h period were higher at most hours in the unsupplemented cows (Figure 2). Regardless of PA, both unsupplemented groups had higher $\mathrm{NH}_{3}-\mathrm{N}$ values than both supplemented groups. The patterns of rumen $\mathrm{NH}_{3}-\mathrm{N}$ concen- trations in both unsupplemented and supplemented treatments were similar. Unsupplemented cows had a peak in rumen $\mathrm{NH}_{3}-\mathrm{N}$ around $1330 \mathrm{~h}$, indicating rumen proteolysis of pasture after a period of high grazing activity following the morning milking. In contrast, sup-

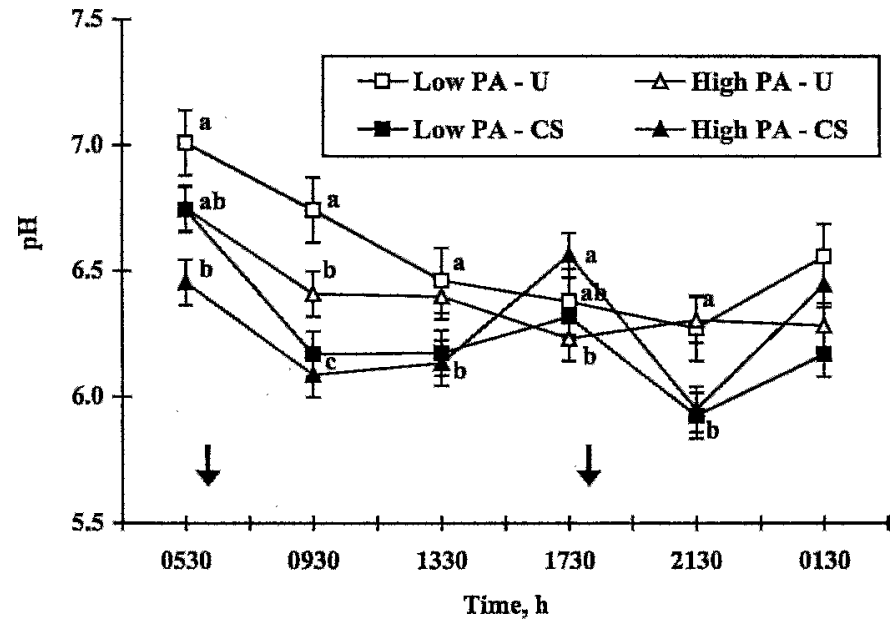

Figure 1. Daily rumen $\mathrm{pH}$ variations of unsupplemented or supplemented dairy cows grazing at two pasture allowances. Arrows indicate time of concentrate feeding for supplemented treatments after milkings.

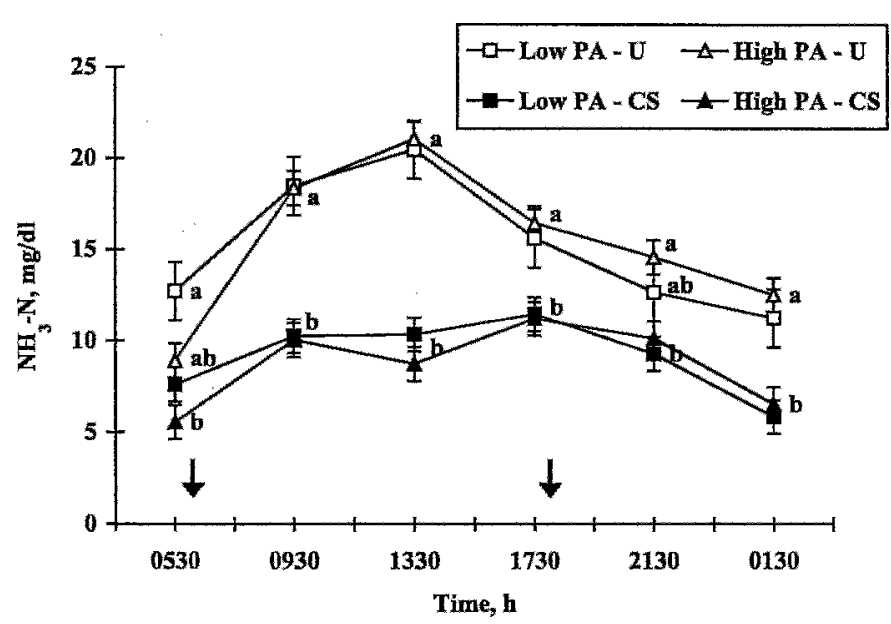

Figure 2. Daily rumen $\mathrm{NH}_{3}-\mathrm{N}$ concentration variations of unsupplemented or supplemented dairy cows grazing at two pasture allowances. Arrows indicate time of concentrate feeding for supplemented treatments after milkings. 
plemented cows had a more constant pattern of $\mathrm{NH}_{3}$ $\mathrm{N}$ in the rumen, indicating the improved utilization of $\mathrm{NH}_{3}-\mathrm{N}$ by the energy provided with the concentrate or a different diurnal pattern of grazing resulting from supplementation.

A significant PA by CS interaction was detected for total VFA concentration $(P<0.05$; Table 6$)$. At a low PA, CS increased total VFA concentration by $13.7 \mathrm{mmol} /$ L, while at high PA, total VFA concentration did not change. The interaction in total VFA followed the interaction found with rumen $\mathrm{pH}$ (Table 6) and total DMI (Table 3). Propionate concentration was increased by CS $(P<0.05)$. Reis and Combs $(2000)$ reported a linear increase in propionate concentration when grazing cows were supplemented with 0,5 , and $10 \mathrm{~kg} / \mathrm{d}$ of concentrate. Concentrate supplementation also significantly increased butyrate concentration $(P<0.05)$, which agrees with results from Reis and Combs (2000). A significant PA by CS interaction was found for the acetate/propionate ratio $(P<0.05)$, and agrees with the reduction in milk fat percentage in the supplemented cows. A linear reduction in acetate/propionate ratio was found in grazing cows supplemented with 0,5 , or 10 $\mathrm{kg} / \mathrm{d}$ (Reis and Combs, 2000).

Neither the volume nor the wet fill of rumen contents were affected by PA or CS $(P>0.05$; Table 6$)$. The wet fill of rumen contents averaged $83.3 \mathrm{~kg}$, a value higher than the $72.4 \mathrm{~kg}$ reported by Reis and Combs (2000). The DM percentage of the rumen content was significantly higher in both supplemented treatments (14.2 vs. $12.5 \% ; P<0.05)$. The higher DM content in the supplemented treatments resulted in a tendency for a higher dry fill of rumen content $(P<0.08)$. Concentrate supplementation tended to also increase disappearance rate and reduce retention time $(P<0.14)$.

\section{Pasture In Situ Rumen Digestion}

The kinetics of pasture DM and NDF rumen digestion are presented in Table 7. For DM degradation, the lag time was not affected by the treatments and averaged $2.2 \mathrm{~h}(P>0.05)$. Neither the soluble nor the insoluble potentially degradable fractions of DM were affected by PA or CS $(P>0.05)$. The soluble fraction averaged $24.2 \%$, a lower value than the $48.4 \%$ reported previously for alfalfa-based pasture (Reis and Combs, 2000). Elizalde et al. (1999) reported that alfalfa had a higher soluble fraction of DM than grasses. The insoluble potentially degradable fraction averaged $56.5 \%(P>0.05)$. The degradation rate of DM was reduced by CS at both PA from 6.8 to $5.4 \% / \mathrm{h}(P<0.05)$. The negative effect of CS on degradation rate of pasture DM may indicate the existence of negative associate effects in the rumen of the supplemented cows. Degradation rates found in our study were lower than those reported by Reis and Combs (2000) and may be related to use of alfalfa-ryegrass pasture. The rate of DM degradation in alfalfa was twice as high as values reported for grasses (13.7 and $6.7 \% / \mathrm{h}$, respectively; Elizalde et al., 1999).

Neither lag time ( $4.3 \mathrm{~h}$ ) nor the soluble fraction (8.9\%) of NDF were affected by treatments $(P>0.05$; Table 7$)$. Concentrate supplementation increased the insoluble potentially degradable fraction of NDF at both PA $(P$ $>0.05$ ). Concentrate supplementation decreased the rate of degradation of NDF from 5.5 to $4.5 \% / \mathrm{h}$ at low $\mathrm{PA}$ and from 4.7 to $3.6 \% / \mathrm{h}$ at high PA $(P<0.05)$. This suggests the existence of minor negative associative effects in the rumen when cows were fed supplements and rumen $\mathrm{pH}$ is reduced. Dairy cows grazing similar pastures to those in our study had a decreased rumen $\mathrm{pH}$ from 6.4 to 6.2 and a reduction in $\mathrm{OM}$ and $\mathrm{NDF}$ digestion when corn was supplemented (Berzaghi et al., 1996).

\section{Efficiency of $\mathbf{N}$ Utilization}

Total $\mathrm{N}$ intake was not affected by treatments $(643 \mathrm{~g} /$ d; $P>0.05$; Table 8). Pasture N intake was numerically reduced by $125 \mathrm{~g} / \mathrm{d}$ by CS (Table 8). Daily N excretion in feces was significantly increased by CS (158 vs. 190 $\mathrm{g} / \mathrm{d} ; P<0.05$ ), while daily $\mathrm{N}$ excretion in urine was significantly reduced by CS (229 vs. $178 \mathrm{~g} / \mathrm{d} ; P<0.05)$. Concentrate supplementation increased excretion of $\mathrm{N}$ in milk (97 vs. $135 \mathrm{~g} / \mathrm{d} ; P<0.06$ ), as expected, because supplemented cows produced more milk and with a higher protein content (Table 4).

Nitrogen partitioning among feces, urine, and milk is also shown in Table 8. The percentage of $\mathrm{N}$ intake excreted in feces was not affected by treatments and averaged $27 \%(P>0.05)$. Kolver et al. (1998) reported $24 \%$ of $\mathrm{N}$ intake partitioned to feces in high producing cows consuming grass pasture and supplemented with $9 \mathrm{~kg} / \mathrm{d}$ of concentrate. Higher feces $\mathrm{N}$ excretion (percentage of $\mathrm{N}$ intake) was reported by Van Vuuren (1993) for dairy cows on grass-based diets supplemented with starch-based concentrates (35\%). A significant PA $\times$ CS interaction was found for $\mathrm{N}$ excreted in urine as a proportion of total $\mathrm{N}$ intake $(P<0.05)$. At low PA, CS reduced the percentage of urinary $\mathrm{N}$ from 42 to $27 \%$. At high PA, the reduction in urine $\mathrm{N}$ as a proportion of total $\mathrm{N}$ intake was from 33 to $28 \%$. In our study, values of urine $\mathrm{N}$ as a proportion of total $\mathrm{N}$ intake for the supplemented cows were similar to those previously reported for supplemented dairy cows consuming grass pasture (30\%; Kolver et al., 1998). Van Vuuren (1993) found in dairy cows fed with ryegrass pasture and 6.6 $\mathrm{kg} / \mathrm{d}$ of a starch-based concentrate, that $38 \%$ of the $\mathrm{N}$ intake was eliminated in urine. For unsupplemented 
Table 7. In situ degradation kinetics of pasture of unsupplemented or supplemented dairy cows grazing at two pasture allowances.

\begin{tabular}{|c|c|c|c|c|c|c|c|c|}
\hline & \multicolumn{2}{|c|}{ Low $\mathrm{PA}^{1}$} & \multicolumn{2}{|c|}{ High $\mathrm{PA}^{2}$} & \multirow[b]{2}{*}{ SEM } & \multicolumn{3}{|c|}{$P<^{3}$} \\
\hline & $\mathrm{U}$ & CS & $\mathrm{U}$ & $\mathrm{CS}$ & & $\mathrm{CS}$ & $\mathrm{PA}$ & $\mathrm{CS} \times \mathrm{PA}$ \\
\hline \multicolumn{9}{|l|}{$\mathrm{DM}$} \\
\hline Lag time, $\mathrm{h}$ & 2.36 & 1.06 & 3.17 & 2.03 & 1.35 & 0.44 & 0.57 & 0.96 \\
\hline Soluble, \% & 20.7 & 26.3 & 27.7 & 22.1 & 4.4 & 0.99 & 0.78 & 0.29 \\
\hline Degradable, $\%$ & 57.7 & 56.4 & 52.9 & 59.0 & 3.4 & 0.55 & 0.79 & 0.36 \\
\hline Rate, $\% / \mathrm{h}$ & 7.6 & 5.3 & 6.0 & 5.4 & 0.4 & 0.01 & 0.12 & 0.09 \\
\hline $\mathrm{ED},{ }^{4} \%$ & 46.7 & 50.3 & 47.4 & 45.1 & 0.9 & 0.62 & 0.13 & 0.06 \\
\hline \multicolumn{9}{|l|}{$\mathrm{NDF}$} \\
\hline Lag time, $\mathrm{h}$ & 3.33 & 4.88 & 4.75 & 4.38 & 0.63 & 0.39 & 0.50 & 0.19 \\
\hline Soluble, \% & 6.6 & 10.6 & 11.5 & 6.9 & 2.6 & 0.93 & 0.83 & 0.17 \\
\hline Degradable, \% & 64.6 & 68.8 & 65.9 & 74.7 & 2.4 & 0.05 & 0.21 & 0.39 \\
\hline Rate, $\% / \mathrm{h}$ & 5.5 & 4.5 & 4.7 & 3.6 & 0.2 & $<0.01$ & 0.01 & 0.92 \\
\hline $\mathrm{ED},{ }^{4} \%$ & 28.3 & 28.7 & 28.4 & 24.6 & 0.9 & 0.15 & 0.10 & 0.09 \\
\hline
\end{tabular}

${ }^{1}$ Low PA-U $=$ Low pasture allowance-unsupplemented, Low PA-CS = low pasture allowance-concentrate supplementation.

${ }^{2}$ High PA-U = High pasture allowance—unsupplemented, High PA-CS = high pasture allowance—concentrate supplementation.

${ }^{3} \mathrm{CS}=$ Main effect of concentrate supplementation, $\mathrm{PA}=$ main effect of pasture allowance, $\mathrm{CS} \times \mathrm{PA}=$ concentrate supplementation by pasture allowance interaction.

${ }^{4} \mathrm{ED}=$ Effective degradability at a rate of passage assumed of $6 \% / \mathrm{h}$.

cows, Van Vuuren (1993) found higher values (54 to $66 \%$ ) than in our study (33 to $42 \%$ ). Concentrate supplementation increased the proportion of total $\mathrm{N}$ partitioned to milk from 15.8 to $20.3 \%$ at both PA $(P<0.05)$. Milk $\mathrm{N}$ as proportion of total $\mathrm{N}$ intake for supplemented cows was lower than that reported by Kolver et al.
$(1998 ; 25 \%)$ for high producing cows supplemented with similar levels of concentrate $(9.2 \mathrm{~kg} \mathrm{DM} / \mathrm{d})$ and consuming similar pastures. Van Vuuren (1993) reported for dairy cows consuming ryegrass as the only feed that between 16 to $23 \%$ of the $\mathrm{N}$ intake was excreted in milk. In agreement with our results, Carruthers and Neil

Table 8. Efficiency of $\mathrm{N}$ utilization of unsupplemented or supplemented dairy cows grazing at two pasture allowances.

\begin{tabular}{|c|c|c|c|c|c|c|c|c|}
\hline & \multicolumn{2}{|c|}{ Low $\mathrm{PA}^{1}$} & \multicolumn{2}{|c|}{ High $\mathrm{PA}^{2}$} & \multirow[b]{2}{*}{ SEM } & \multicolumn{3}{|c|}{$P<^{3}$} \\
\hline & $\mathrm{U}$ & $\mathrm{CS}$ & $\mathrm{U}$ & $\mathrm{CS}$ & & $\mathrm{CS}$ & PA & $\mathrm{CS} \times \mathrm{PA}$ \\
\hline \multicolumn{9}{|l|}{ N Intake, g/d } \\
\hline Supplement & 11.8 & 170.4 & 10.9 & 178.4 & 2.8 & 0.06 & 0.49 & 0.47 \\
\hline Pasture & 579.3 & 483.8 & 646.9 & 492.4 & 20.4 & 0.12 & 0.28 & 0.22 \\
\hline Total & 591.1 & 654.2 & 657.8 & 670.8 & 19.4 & 0.12 & 0.22 & 0.16 \\
\hline Fecal N, g/d & 156.9 & 184.3 & 158.7 & 196.6 & 4.6 & 0.05 & 0.18 & 0.17 \\
\hline Urine $\mathrm{N},{ }^{4} \mathrm{~g} / \mathrm{d}$ & 244.5 & 172.9 & 213.4 & 182.6 & 9.3 & 0.04 & 0.37 & 0.20 \\
\hline Milk N, g/d & 92.3 & 131.2 & 100.9 & 138.0 & 4.9 & 0.06 & 0.08 & 0.58 \\
\hline $\mathrm{N}$ balance, $\mathrm{g} / \mathrm{d}$ & 97.4 & 165.8 & 184.8 & 153.6 & 20.9 & 0.47 & 0.32 & 0.03 \\
\hline $\mathrm{N}$ digestibility, \% & 73.3 & 71.9 & 75.7 & 70.6 & 0.6 & 0.08 & 0.20 & 0.09 \\
\hline $\mathrm{BV},{ }^{\circ} \%$ & 42.2 & 61.9 & 55.8 & 60.6 & 2.5 & 0.18 & 0.16 & 0.01 \\
\hline \multicolumn{9}{|l|}{$\mathrm{N}, \% \mathrm{~N}$ intake } \\
\hline Fecal N & 26.7 & 28.1 & 24.3 & 29.4 & 0.6 & 0.08 & 0.20 & 0.09 \\
\hline Urine $\mathrm{N}$ & 41.8 & 27.3 & 33.2 & 27.8 & 1.7 & 0.16 & 0.17 & 0.03 \\
\hline Milk N & 15.7 & 20.0 & 15.8 & 20.6 & 0.9 & 0.02 & 0.59 & 0.21 \\
\hline
\end{tabular}

${ }^{1}$ Low PA-U = Low pasture allowance-unsupplemented, Low PA-CS = low pasture allowance—concentrate supplementation.

${ }^{2}$ High PA-U = High pasture allowance — unsupplemented, High PA-CS = high pasture allowance—concentrate supplementation.

${ }^{3} \mathrm{CS}=$ Main effect of concentrate supplementation, $\mathrm{PA}=$ main effect of pasture allowance, $\mathrm{CS} \times \mathrm{PA}=$ concentrate supplementation by pasture allowance interaction.

${ }^{4}$ Total urine volume estimated using daily creatinine excretion $(\mathrm{mg} / \mathrm{kg}$ of $\mathrm{BW} / \mathrm{d})$ as internal marker (Valadares et al., 1999).

${ }^{5}$ Biological value $=[(\mathrm{N}$ intake $-($ fecal $\mathrm{N}$ output + urine $\mathrm{N}$ output $)) /(\mathrm{N}$ intake - fecal output $)] \times 100$. 
Table 9. Grazing behavior and ruminating time of unsupplemented or supplemented dairy cows grazing at two pasture allowances.

\begin{tabular}{|c|c|c|c|c|c|c|c|c|}
\hline & \multicolumn{2}{|c|}{ Low $\mathrm{PA}^{1}$} & \multicolumn{2}{|c|}{ High $\mathrm{PA}^{2}$} & \multirow[b]{2}{*}{ SEM } & \multicolumn{3}{|c|}{$P<^{3}$} \\
\hline & $\mathrm{U}$ & $\mathrm{CS}$ & $\mathrm{U}$ & $\mathrm{CS}$ & & $\mathrm{CS}$ & PA & $\mathrm{CS} \times \mathrm{PA}$ \\
\hline Grazing time, $\min / \mathrm{d}$ & 609 & 534 & 626 & 522 & 37 & 0.02 & 0.94 & 0.70 \\
\hline Total bites, bites/d & 34,419 & 28,501 & 35,235 & 28,563 & 2706 & 0.03 & 0.87 & 0.89 \\
\hline Biting rate, bites/min & 56 & 54 & 56 & 55 & 2 & 0.55 & 0.74 & 0.72 \\
\hline Bite mass, ${ }^{4}$ g DM/bite & 0.55 & 0.55 & 0.60 & 0.59 & 0.05 & 0.97 & 0.34 & 0.96 \\
\hline Ruminating time,${ }^{5} \mathrm{~min} / \mathrm{d}$ & 263 & 183 & 210 & 116 & 41 & 0.04 & 0.16 & 0.87 \\
\hline
\end{tabular}

\footnotetext{
${ }^{1}$ Low PA-U = Low pasture allowance-unsupplemented, Low PA-CS = low pasture allowance—concentrate supplementation.

${ }^{2}$ High PA-U = High pasture allowance—unsupplemented, High PA-CS = high pasture allowance —concentrate supplementation.

${ }^{3} \mathrm{CS}=$ Main effect of concentrate supplementation, $\mathrm{PA}=$ main effect of pasture allowance, $\mathrm{CS} \times \mathrm{PA}=$ concentrate supplementation by pasture allowance interaction.

${ }^{4}$ Bite size $=$ Pasture DMI/(grazing time $\times$ biting rate).

${ }^{5}$ Measured over $22 \mathrm{~h} 30 \mathrm{~min} / \mathrm{d}$.
}

(1997) reported an increase in fecal $\mathrm{N}$ and milk $\mathrm{N}$, and a reduction in urine $\mathrm{N}$ as proportions of $\mathrm{N}$ intake for dairy cows consuming ryegrass pasture and supplemented with NSC, compared to cows without NSC supplementation.

\section{Grazing Behavior and Ruminating Time}

Data on grazing behavior are given in Table 9. Pasture DMI is described as the product of grazing time (min/d), biting rate (bites/min), and bite mass (g DM/ bite). Concentrate supplementation reduced grazing time at both PA $(P<0.05)$. In two experiments with dairy cows grazing a ryegrass pasture, Pulido and Leaver (2001) reported lower grazing time when unsupplemented (531 to $540 \mathrm{~min} / \mathrm{d}$ ) but similar grazing time when supplemented with $6 \mathrm{~kg} / \mathrm{d}$ of concentrate (515 to $526 \mathrm{~min} / \mathrm{d})$. Although the interaction between PA and CS was not significant, the reduction in grazing time was less at the low PA (75 min/d) than at the high PA (104 $\mathrm{min} / \mathrm{d})$. The reduction in grazing time with CS is consistent with the reduction in pasture DMI previously described (Table 3 ). The significantly greater reduction in pasture DMI at the high PA is in agreement with the numerically greater reduction in grazing time at the high PA.

When expressed per kilogram of concentrate supplemented, overall grazing time was reduced by $11 \mathrm{~min} / \mathrm{kg}$ of concentrate. McGilloway and Mayne (1996) reported reductions in grazing time of 15 to $22 \mathrm{~min} / \mathrm{kg}$ concentrate. In a later study, Sayers (1999) reported a reduction in grazing time of 16 to $20 \mathrm{~min} / \mathrm{kg}$ of concentrate when amount of supplement was increased from 5 to 10 $\mathrm{kg} / \mathrm{d}$. In agreement with our results, Pulido and Leaver (2001) reported a lower reduction in grazing time per kilogram of concentrate (4 to $10 \mathrm{~min}$ ) for grazing cows producing more than $30 \mathrm{~kg} / \mathrm{d}$ of milk. Therefore, a reduction in grazing time is a common effect with CS, and has been proposed as an explanation for substitution rate (McGilloway and Mayne, 1996).

Biting rate was not affected by PA or CS ( 55 bites/ min; $P>0.05$; Table 9). Previous grazing studies reported no effect of CS on biting rate (Arriaga-Jordan and Holmes, 1986; Rook et al., 1994). Arriaga-Jordan and Holmes (1986) reported data from cows grazing a ryegrass pasture and supplemented either with 1 or 6 $\mathrm{kg} / \mathrm{d}$ of a barley-based concentrate, and found that level of supplementation did not affect biting rate (63 bites/ min). Concentrate supplementation also did not affect biting rate (53 bites/min) of dairy cows grazing a ryegrass-white clover pasture (Rook et al., 1994).

Bite mass was not altered by PA or CS and averaged $0.57 \mathrm{~g} \mathrm{DM} / \mathrm{bite}(P>0.05$; Table 9$)$. No difference was anticipated because cows of all treatments grazed a pasture that was offered on a daily basis at similar pregrazing pasture mass and pasture height (Table 2). It is well known that bite mass is principally determined by pasture characteristics such as pregrazing pasture mass and pasture height (McGilloway et al., 1999).

Ruminating time values are for $21 \mathrm{~h} 30 \mathrm{~min} / \mathrm{d}$ because the recorders were removed from the cows during milking time (Table 9). Concentrate supplementation reduced the time that cows expended ruminating by 87 $\mathrm{min} / \mathrm{d}(P<0.05)$ or by $10 \mathrm{~min} / \mathrm{kg}$ of concentrate at the low PA and by $12 \mathrm{~min} / \mathrm{kg}$ concentrate at the high PA. The reduction in ruminating time with $\mathrm{CS}$ is in agreement with the reduction in rumen $\mathrm{pH}$ observed when cows were fed supplement (Table 6). Ruminating time values in our study are well below those reported by previous studies with grazing cows (around $400 \mathrm{~min} /$ d; Sayers, 1999). Although our lower values may be 
related to the fact that recorders were removed from the cows before and during milking times (time of day when cows had high ruminating activity based on visual observations), assuming that during that time cows were ruminating, the time would be lower than 400 $\mathrm{min} / \mathrm{d}$. Ruminating time was not affected by level of concentrate supplementation $(0,3$, or $6 \mathrm{~kg} / \mathrm{d})$ and averaged $444 \mathrm{~min} / \mathrm{d}$ in dairy cows grazing a ryegrass pasture (Sayers, 1999). Pulido and Leaver (2001) also reported no effect of concentrate level on ruminating time of dairy cows grazing a ryegrass pasture (average: 389 $\mathrm{min} / \mathrm{d}$ ). In agreement with our results, Sayers (1999) reported a reduction in ruminating time when the amount of concentrate was increased from 5 to $10 \mathrm{~kg} /$ $\mathrm{d}$ in high producing cows grazing ryegrass pasture (433 vs. $405 \mathrm{~min} / \mathrm{d}$ or $6 \mathrm{~min} / \mathrm{kg}$ of concentrate) that also produced a reduction in rumen $\mathrm{pH}$ (6.00 vs. 5.75).

\section{Reasons for Substitution Rate}

Two hypotheses have been proposed to explain the substitution rate of forage by concentrate. First, the substitution rate may be produced by negative associative effects in the rumen of grazing cows supplemented with concentrates (Dixon and Stockdale, 1999). Second, substitution rate may be related to reductions in grazing time when cows on pasture are fed supplement (McGilloway and Mayne, 1996). In this study, both negative associative effects in the rumen and the reduction in grazing time influenced the substitution rate. Those effects were likely more important when cows grazed at the high PA, since a higher substitution rate was found with lower PA ( 0.55 vs. $0.26 \mathrm{~kg}$ pasture $/ \mathrm{kg}$ of concentrate).

Both supplemented treatments had lower rumen $\mathrm{pH}$ (Table 6), lower rumen degradation rates of pasture (Table 7), and lower fiber digestibility (Table 3). Rumen $\mathrm{pH}$ was reduced by $\mathrm{CS}$ to 6.27 , which is not likely low enough to have negative effects on the cellulolytic population in the rumen (Satter et al., 1999). Therefore, the reduction in fiber digestibility may be related to the negative impact of starch per se on fiber digestibility (Satter et al., 1999).

Supplemented cows also spent less time grazing (Table 9). At the low PA, grazing time was reduced $75 \mathrm{~min} /$ $\mathrm{d}$ with supplementation. With the biting rate (55 bites/ $\mathrm{min})$ and bite mass (0.55 g DM/bite), the reduction in grazing time would reduce pasture DMI by $2.3 \mathrm{~kg} / \mathrm{d}$. Pasture DMI, when measured by the fecal marker, was $2.0 \mathrm{~kg} / \mathrm{d}$ lower with CS (Table 3). Therefore, at a low PA, a reduced grazing time explained all of the reduction in pasture intake. At the high PA, CS reduced grazing time $104 \mathrm{~min} / \mathrm{d}$. With a biting rate of $56 \mathrm{bites} / \mathrm{min}$ and bite mass of $0.60 \mathrm{~g} \mathrm{DM} / \mathrm{bite}$, the reduction in grazing time would reduce pasture DMI by $3.5 \mathrm{~kg} / \mathrm{d}$. Pasture DMI, measured by the fecal marker, was reduced 4.4 $\mathrm{kg} / \mathrm{d}$ by CS (Table 3). Therefore, at a high PA, the reduction in grazing time explained about $80 \%$ of the reduced pasture intake $(3.5 \mathrm{~kg} / 4.4 \mathrm{~kg})$. The remaining $20 \%$ may be related to negative associative effects in the rumen. For example, the decrease in apparent digestibility of NDF by CS was greater at the high PA than at the low PA (4.3 vs. 1.1 percentage points, respectively; Table 3 ). The greater reduction in grazing time at high PA may also be related in this treatment to the higher NDF intake as \% of BW compared to the other three treatments (1.83 vs. $1.65 \%$; Table 3 ).

\section{CONCLUSIONS}

Concentrate supplementation reduced pasture DMI, but the reduction in pasture DMI was significantly greater when cows grazed at the high PA $(4.4 \mathrm{~kg} / \mathrm{d})$ than at the low PA $(2.0 \mathrm{~kg} / \mathrm{d})$. Therefore, the substitution of pasture for concentrate was greater at the high PA $(0.55$ $\mathrm{kg}$ of pasture/kg of concentrate) than at the low PA $(0.26 \mathrm{~kg}$ of pasture $/ \mathrm{kg}$ of concentrate). Milk production was increased by CS, but the increase was greater at a low PA (from 19.1 to $29.7 \mathrm{~kg} / \mathrm{d}$ ) than at a high PA (from 22.2 to $29.9 \mathrm{~kg} / \mathrm{d}$ ). The milk response to CS was greater at low PA (1.36 vs. $0.96 \mathrm{~kg}$ of milk/kg of concentrate). Substitution rate was related to negative associative effects in the rumen, including a reduction in rumen $\mathrm{pH}$, a lower rumen degradation rate of pasture, a decrease in apparent digestibility of NDF, and a reduction in grazing time with supplementation.

\section{ACKNOWLEDGMENTS}

The authors thank undergraduate students Julie Hazelton and Barbie Berrang for assistance in animal care, sampling, and laboratory analyses; and Jim Homan for assistance in pasture management (fencing and watering).

\section{REFERENCES}

Arriaga-Jordan, C. M., and W. Holmes. 1986. The effect of concentrate supplementation on high yielding dairy cows under two systems of grazing. J. Agric. Sci. (Camb.) 107:453-461.

Association of Official Analytical Chemists. 1990. Official Methods of Analysis. 15th ed. AOAC, Arlington, VA.

Berzaghi, P., J. H. Herbein, and C. E. Polan. 1996. Intake, site, and extent of nutrient digestion of lactating cows grazing pasture. J. Dairy Sci. 79:1581-1589.

Carruthers, V. R., and P. G. Neil. 1997. Milk production and ruminal metabolites from cows offered two pasture diets supplemented with non-structural carbohydrate. N.Z. J. Agric. Res. 40:513-521.

Chen, X. B. 1989. Excretion of purine derivatives by sheep and cattle and its use for estimation of absorbed/microbial protein. Ph.D. Diss., Univ. Aberdeen, Scotland.

Dalley, D. E., J. R. Roche, C. Grainger, and P. J. Moate. 1999. Dry matter intake, nutrient selection, and milk production of dairy 
cows grazing rainfed perennial pastures at different herbage allowances in spring. Aust. J. Exp. Agric. 39:923-931.

Delaby, L., J. L. Peyraud, and R. Delagarde. 2001. Effect of the level of concentrate supplementation, herbage allowance, and milk yield at turn-out on the performance of dairy cows in mid-lactation at grazing. Anim. Sci. 73:171-181.

Dixon, R. M., and C. R. Stockdale. 1999. Associative effects between forages and grains: consequences for feed utilization. Aust. J. Agric. Res. 50:757-773.

Elizalde, J. C., N. R. Merchen, and D. B. Faulkner. 1999. In situ dry matter and crude protein degradation of fresh forages during the spring growth. J. Dairy Sci. 82:1978-1990.

Gonda, H. L. 1995. Nutritional status of ruminants determined from excretion and concentration of metabolites in body fluids. Ph.D. Diss. Swedish Univ. of Agricultural Sciences. Dep. Anim. Nutr. and Management. Uppsala.

Grainger, C., and G. L. Mathews. 1989. Positive relation between substitution rate and pasture allowance for cows receiving concentrates. Aust. J. Exp. Agric. 29:355-360.

Holden, L. A., L. D. Muller, G. A. Varga, and P. J. Hillard. 1994. Ruminal digestion and duodenal nutrient flows in dairy cows consuming grass as pasture, hay, or silage. J. Dairy Sci. 77:3034-3042.

Kellaway, R., and S. Porta. 1993. Feeding concentrates supplements for dairy cows. Dairy Res. Dev. Corp. Australia.

Kolver, E. S., and L. D. Muller. 1998. Performance and nutrient intake of high producing Holstein cows consuming pasture or a total mixed ration. J. Dairy Sci. 81:1403-1411.

Kolver, E. S., L. D. Muller, G. A. Varga, and T. J. Cassidy. 1998. Synchronization of ruminal degradation of supplemental carbohydrate with pasture nitrogen in lactating dairy cows. J. Dairy Sci. 81:2017-2028.

Krishnamoorthy, U., T. V. Muscato, C. J. Sniffen, and P. J. Van Soest. 1982. Nitrogen fractions in selected feedstuffs. J. Dairy Sci. 65:217-225.

Lykos, T., and G. A. Varga. 1995. Effect of heat treatment and particle size on degradation characteristics of protein and carbohydrate sources in situ. J. Dairy. Sci. 78:1789-1801.

McGilloway, D. A., and C. S. Mayne. 1996. The importance of grass availability for the high genetic merit dairy cow. Page 135 in Recent Advances in Animal Nutrition. P. C. Garnsworthy, J. Wiseman, and W. Haresign, ed. Nottingham Univ. Press. UK.

McGilloway, D. A., A. Cushnahan, A. S. Laidlaw, C. S. Mayne, and D. J. Kilpatrick. 1999. The relationship between level of sward height reduction in a rotationally grazed sward and short-term intake rates of dairy cows. Grass Forage Sci. 54:116-126.

Meijs, J. A. C., and J. A. Hoekstra. 1984. Concentrate supplementation of grazing dairy cows. 1. Effect of concentrate intake and herbage allowance on herbage intake. Grass Forage Sci. 39:59-66.

Muller, L. D., and S. L. Fales. 1998. Supplementation of cool-season grass pastures for dairy cattle. Page 335 in Grass for Dairy Cattle. J. H. Cherney and D. J. R. Cherney, ed. CAB International.

National Research Council. 1989. Nutrient requirements of dairy cattle. 6th rev. ed. National Academic Press, Washington, DC.
National Research Council. 2001. Nutrient requirements of dairy cattle. 7th rev. ed. Natl. Academic Press, Washington, DC.

Opatpatanakit, Y., R. C. Kellaway, and I. J. Lean. 1993. Substitution effects of feeding rolled barley grain to grazing dairy cows. Anim. Feed Sci. Technol. 42:25-38.

Petch, S. F., A. M. Bryant, and A. R. Napper. 1997. Effects of pasture intake and grain supplementation on milk nitrogen fractions. Proc. N.Z. Soc. Anim. Prod. 57:154-156.

Pulido, R. G., and J. D. Leaver. 2001. Quantifying the influence of sward height, concentrate level, and initial milk yield on the milk production and grazing behaviour of continuously stocked dairy cows. Grass For. Sci. 56:57-67.

Reis, R. B., and D. K. Combs. 2000. Effects of increasing levels of grain supplementation on rumen environment and lactation performance of dairy cows grazing grass-legume pasture. J. Dairy Sci. 83:2888-2898.

Reis, R. B., F. San Emeterio, D. K. Combs, L. D. Satter, and H. N. Costa. 2001. Effects of corn particle size and source on performance of lactating cows fed direct-cut grass-legume forage. J. Dairy Sci. 84:429-441.

Robaina, A. C., C. Grainger, P. Moate, J. Taylor, and J. Stewart. 1998. Responses to grain feeding by grazing dairy cows. Aust. J. Exp. Agric. 38:541-549.

Rook, A. J., C. A. Huckle, and P. D. Penning. 1994. Effects of sward height and concentrate supplementation on the ingestive behaviour of spring-calving dairy cows grazing grass-clover swards. Appl. Anim. Behav. Sci. 40:101-112.

Rutter, S. M., R. A. Champion, and P. D. Penning. 1997. An automatic system to record foraging behaviour in free-ranging ruminants. Appl. Anim. Behav. Sci. 54:185-195.

SAS User's Guide: Statistics, Version 8.01 Edition. 1999. SAS Inst., Inc., Cary, NC.

Satter, L. D., H. G. Jung, A. M. Van Vuuren, and F. M. Engels. 1999. Challenges in the nutrition of high-producing ruminants. Page 609 in Nutritional Ecology of Herbivores. H. G. Jung, and G. C. Fahey, Jr., ed. ASAS, Savoy, IL.

Sayers, H. J. 1999. The effect of sward characteristics and level and type of supplement on grazing behaviour, herbage intake and performance of lactating dairy cows. Ph.D. Diss. Queen's Univ. Belfast. The Agricultural Research Institute of Northern Ireland, Hillsborough.

Smith, D. 1981. Removing and analyzing carbohydrates from plant tissue. Wisconsin Agric. Exp. Stn. Rep. R2107, Madison.

Stakelum, G. 1986. Herbage intake of grazing dairy cows. 1. Effect of autumn supplementation with concentrates and herbage allowance on herbage intake. Irish J. Agric. Res. 25:31-40.

Stockdale, C. R. 1999. The nutritive characteristics of herbage consumed by grazing dairy cows affect milk yield responses obtained from concentrate supplementation. Aust. J. Exp. Agric. 39:379-387.

Valadares, R. F. D., G. A. Broderick, S. C. Valadares Filho, and M. K. Clayton. 1999. Effect of replacing alfalfa silage with high moisture corn on ruminal protein synthesis estimated from excretion of total purine derivatives. J. Dairy Sci. 82:2686-2696.

Van Vuuren, A. M. 1993. Digestion and nitrogen metabolism of grassfed dairy cows. Ph.D. Diss. Wageningen Univ., The Netherlands. 